\title{
Subsidy Entrepreneurs: an Inquiry into Firms Seeking Public Grants
}

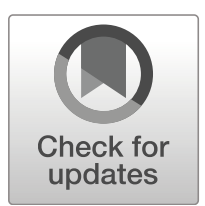

\section{Anders Gustafsson $^{1}$ (D) Patrik Gustavsson Tingvall ${ }^{2}$. Daniel Halvarsson ${ }^{3}$}

Received: 7 February 2019 / Revised: 8 August 2019 / Accepted: 12 August 2019 /

Published online: 21 November 2019

(C) The Author(s) 2019

\begin{abstract}
This paper studies the incentives and characteristics of firms that apply for, and eventually receive, one or multiple governmental grants intended to stimulate innovation and growth. The analysis departs from a contest model in which entrepreneurs are free to allocate their effort between production and seeking grants. The results suggest that highly productive entrepreneurs abstain from seeking grants, moderately productive firms allocate a share of their effort to grant seeking, and low-productivity firms allocate most resources to seeking grants. Due to their efforts in seeking grants, these low-productive subsidy entrepreneurs also have a relatively high probability of receiving the grants. Using comprehensive data over grants from the three largest grant-distributing agencies in Sweden, we find concordant evidence of a negative relation between the probability of receiving a grant and firm productivity. As we go from single- to multiple-grant-supported firms, this negative relation becomes more pronounced.
\end{abstract}

Keywords Firm subsidies · Industrial policy · Innovation policy · Entrepreneurship

JEL Classification $\mathrm{H} 25 \cdot \mathrm{O} 38 \cdot \mathrm{P} 16 \cdot \mathrm{D} 72 \cdot \mathrm{L} 52$

\section{Introduction}

The importance of innovation as a driver of economic growth has made innovation policy one of the most discussed economic and political topics (Becker 2015). In recent years,

Anders Gustafsson

anders.gustafsson@ratio.se

Patrik Gustavsson Tingvall

patrik.tingvall@kommers.se

1 Örebro University \& the Research Institute of Industrial Economics (IFN), Örebro, Sweden

2 The European Institute of Japanese Studies (EIJS), Stockholm School of Economics \& National Board of Trade Sweden, Stockholm, Sweden

3 The Ratio Institute, Stockholm, Sweden 
it has become common for governments to provide various selective policy instruments directed to firms with the intention to stimulate innovation, $R \& D$, and growth. One example is direct cash transfers in the form of grants. These grants are often, but not always, directed to small- and medium-sized enterprises (SMEs) due to their lack of credit and high-growth potential. Hence, a shortage of credits along with the positive spillover effects that arise from growth and innovation suggests that governments have a role to play in fostering innovation and firm growth. With a multitude of governmental subsidies available to firms, this type of grants nowadays represents an integral component of the financial ladder for many SMEs. Given the extent of direct support programs, it has become increasingly important to analyze and understand the efficiency, and the type of incentives they create for firms. If the objectives of public agents who seek appropriate firms and projects to fund are at odds with the incentives faced by firms, such mismatch can lead to less qualified firms seeking and receiving the grants.

Incentive structures are central to our understanding of economic policy, yet little attention has been directed towards the selection process that underlies the decision by entrepreneurs to allocate resources for the purpose of seeking grants. According to Aerts et al. (2006), the decision to seek and participate in publicly supported grant programs is typically modeled ad hoc to conform with the often limited data that is available. ${ }^{1}$ To the extent selection is considered, the selection process has often been subordinated to the effects of the grant.

The purpose of this paper is to analyze the selection process of firms that apply for, and eventually receive, one or many government grants. To the best of our knowledge, this is the first paper that distinguishes single- from multiple-supported firms. The analysis is based on comprehensive data over the public grants that were distributed to firms by the three largest distributing agencies in Sweden over the period 1997 to 2013. Data on grants contains information on the type of grant, amount received, and the time at which it was handed out. What we do not have information on, however, is which firms that applied for a grant but were denied it. In total, there were more than fifteen thousand firms that receives at least one grant out of which about 20 percent received more than one grant.

To theorize about selection, we present a simple and stylized model over the decision by entrepreneurs to allocate resources to seeking grants. It takes the form of a contest model (c.f. Tullock 1980; Stein 2002), where entrepreneurs face the decision of allocating their effort between grant seeking and market production. The source of heterogeneity is given by the entrepreneurs' innate productivity that is used to leverage market production. The idea is that an entrepreneur, by seeking the grant, forgoes the profit earned in production for the expected profit from winning the contest, and hence receiving the grant. In equilibrium, entrepreneurs with sufficiently high productivity abstain from grant seeking altogether and use all their effort to production. For contesting entrepreneurs, on the other hand, the amount of effort expended to acquire the grant is inversely related to the level of productivity. For the lowest productive entrepreneurs, most if not all effort is allocated to seeking the grant. By implication, these kinds of subsidy entrepreneurs are also more likely to receive the grant. And without additional assumptions about the effect of the grant, low-productivity entrepreneurs are likewise more probable to receive additional grants.

To examine the theoretical predictions of the contest model, we focus the empirical analysis on how single- and multiple-supported firms deviate from non-supported firms with

\footnotetext{
${ }^{1}$ Often times, data is only available at the sector level, which can only give limited insight into the driving microeconomic factors.
} 
respect to labor productivity, but also other firm-level characteristics, i.a. the firm's age and size, wages, and skill intensity. Importantly, this analysis is made possible by the merging of register-based data on firms from Statistics Sweden (SCB) with the grant data that has been made available to us from The Swedish Agency for Growth Policy Analysis (Growth Analysis).

Using Swedish data, it is our contention that Sweden constitutes a particularly relevant case for studying the economic implications of selective industrial policy and potential strategic behavior for the following reasons. Sweden is regarded as one of the most innovative countries in the world, but it is home to a complex system of public innovation programs with many small- and medium-sized agencies funding similar projects (OECD 2016). The existence of overlapping agencies and programs may enhance the formation of firms specializing in seeking grants. Furthermore, Sweden is a country with low, but not non-existent, levels of corruption, which facilitates in isolating the firm effect from other political incentives that might surround grants (Dahlberg and Johansson 2002; Svaleryd and Vlachos 2009). Recent research on grants has examined other countries, e.g., China, where corruption is more widespread and thus confounds the firm-level analysis ( $\mathrm{Du}$ and Mickiewicz 2016; Cheng et al. 2019).

To estimate the model, we apply a set of logistic and count data models to capture various aspects of the selection process that characterize single and multiple-supported firms. Specifically, we estimate three sets of models: the first is a logistic model of the probability of receiving a grant. The results suggest that subsidized firms have, on average, lower productivity and higher skill intensity than non-supported firms. These characteristics are further strengthened when distinguishing single-supported firms from multiple-supported firms, in line with the model of grant-seeking entrepreneurs. Similar results are found when we estimate the difference between non-, single-, and multiple-supported firms with a ordinal logit model. To complement these models, we also consider a count model over the number of received grants (1st, 2nd, and 3rd, ...) and obtain similar results while also finding that multiple-subsidized firms have higher wages than other firms. While the evidence is not conclusive, the results support the notion that a comprehensive system of available grants opens up for the possibility of low-productivity firms to specialize in grant seeking rather than market production as a viable strategy for profit maximization.

\section{Firm Subsidies and Strategic Firm Behavior}

Many governments believe that grants can help to increase targeted firms' competitiveness and increase their rate of innovation. It is therefore not surprising that an extensive series of papers analyzes the impact of grants and participation in grant seeking on the competitiveness of participating firms. In a survey, Zúñiga-Vicente et al. (2014) summarize the results from 77 studies on different support schemes, and although the results vary across studies, one finding is that the impact of a grant tends to be larger for smaller than for larger firms. This line of reasoning is further supported by González et al. (2005), Bronzini and Iachini (2010), Lööf and Hesmati (2004), and Criscuolo et al. (2012). We may also note Guo et al. (2014), who, using Chinese data on the Innovation Fund program, find that the effects of program participation increased when the project screening became more decentralized. Hence, while there is an extensive literature on the impact of governmental subsidies, less are however known about the drivers and characteristics of firms participating in these programs. 
Klette et al. (2000) and David et al. (2000) analyze innovation policies, and both suggest that participation in $R \& D$ programs is not random. They argue that to improve our understanding of the effects of firm grants and subsidies, we need to acquire a better understanding of the decisions of both public agencies and firms. Thus, we must emphasize the strategic aspect of selective policies.

One paper explicitly focuses on the determinants of participation in publicly sponsored programs is Blanes and Isabel (2004), who find that skill-intensive firms with previous R\&D experience are over-represented in subsidy programs. ${ }^{2}$ In addition, they also report that firms with low cash-flow, which might indicate credit constraints, are over-represented in subsidy programs. Further attempts to identify the factors determining program participation include Blanes and Isabel (2004) and Afcha (2012), who both find that technological co-operation, previous R\&D experience, and a high firm skill intensity are positively correlated with participation in publicly sponsored R\&D programs. Similar results are obtained by Cerulli and Poti (2008), who analyze public R\&D subsidies using Italian data, and Czarnitzki and Delanote (2014), who uses German data. In addition, Lööf and Hesmati (2004) find that firms that received public R\&D support could be characterized as $R \& D$ intensive and credit constrained. We also note that Catozzella and Vivarelli (2011) show that the probability of obtaining a subsidy was higher if the firm had a track record of conducting export-oriented product and process innovations and cooperated with universities and/or research institutes. Other papers that specifically have looked at the selection of firms into selective subsidy programs are Silva et al. (2017), who uses data from Portugal on R\&D subsidies and finds that mainly large firms with previous $R \& D$ experience gets subsidies. Aschhoff (2010) specifically looks at which firms receives R\&D subsidies with German data and found that having participated in public support programs is a key factor in determining who receives a grant, which in turn may be attributed to learning by doing and experience of the grant-seeking process.

Several papers have looked at selection of firms into Spanish R\&D subsidies (Heijs 2005; Huergo and Trenado 2010; Arqué-Castells and Mohnen 2015). Their main finding has been that there are barriers for firms to start new $R \& D$ that in turn prevents them from applying for grants. This results in a situation were grants often target relativley large firms with high potential and that the responsible agencies tries to pick national champions.

Takalo et al. (2013) uses Finnish data to model the costs of application for the firms. They find that that the more profitable a project is for a firm, the less likely they are to apply for funding due to opportunity costs.

Taken together, these results suggest that not only do firm characteristics matter for the probability of receiving a grant but also that earlier experiences in public support programs and innovation behavior. Public agencies often try to "pick winners" to ensure that their funding leads to new results. A report by Feldman and Kelley (2001) on the winners of awards from the Advanced Technology Program in the USA finds evidence suggesting that the number of business and university linkages held by a firm positively affects the probability of winning a contest. In a similar vein, Hussinger (2008) found that the probability of receiving R\&D subsidies was positively correlated with previously having received subsidies, as well as with past patenting experience. One feature of most previous research on firms participating in governmental support programs is that it has mainly studied the selection of firms into R\&D subsidies, whereas this paper looks at a broader set of subsidies, including not only innovation programs but also various regional and energy based grants. In

\footnotetext{
${ }^{2}$ Henceforth, we use the terms "subsidies" and "grants" interchangeably.
} 
addition, while several papers attribute previous experience as an important factor in receiving grants, few attribute this increase in knowledge as arising from the firms specializing in seeking grants.

A related literature examines rent-seeking, where firms divert resources to gain either direct transfers or protection in the form of tariffs and entry barriers (Grossman and Helpman 1994; Baldwin and Robert-Nicoud 2007). Note that grant seeking can be viewed as an activity that diverts resources from productive work toward non-directly productive activities such as applying for governmental grants, whereas the grant may or may not be put to productive use. In the entrepreneurship literature, the link between entrepreneurial activities and rent-seeking has been studied from various perspectives. One starting point for this line of work is Baumol (1990), who argue the the allocation of entrepreneurial activities between unproductive rent-seeking and productive work is ultimately governed by the payoffs offered by the society. Hence, policy can influence the allocation of entrepreneurial talent. This line of reasoning is further analyzed by Lucas and Fuller (2017), who takes an explicit institutional perspective on entrepreneurship and rent-seeking.

In summary, there is extensive work analyzing different perspectives on selective firm supports such as program design, entrepreneurial consequences, and competitiveness effects. However, the possibility that firms will specialize in grant-seeking activities as a profit-maximizing strategy has not yet been studied in detail.

\section{A Model of Grant-Seeking Entrepreneurs}

To theorize about selection into seeking grants, we consider the perspective of an entrepreneur. In deciding on an viable framework, we need to take into account (i) a procedure for distributing a single grant among many contesting participants; (ii) heterogeneity in the set of participants; and (iii) a mechanism that relates entrepreneurs to participation in the procedure.

One such procedure can be found in the literature on contests. The generic contest model, in the tradition of Tullock (1980), describes a contest in which a given number of homogeneous participants expend a certain amount of resources to maximize their expected profit. Introducing many heterogeneous agents is particularly relevant for the purposes of this paper. Heterogeneity can enter the model in at least three ways. First, it can come in the form of the heterogeneous valuation of grants among the participants (see, e.g., Stein 2002). Another type of heterogeneity involves the contest production function, e.g., some participants are better at grant seeking than others. A third type of heterogeneity comes in the form of different financial constraints (Che and Gale 1997). Yamazaki (2008) describes the conditions that guarantee the existence and uniqueness of a pure strategy Nash (asymmetric) equilibrium with all three types of heterogeneities.

The literature offers little in the way of guidance on how to integrate entrepreneurs into the contest model. In the rest of this section, we present a simple version of the contest model that incorporates entrepreneurs and derive some of its main implications. The main purpose is not to derive a structural equation to be estimated but rather to present a corpus of theory from which hypotheses can be derived about the character of the entrepreneurs seeking and, later, receiving grants.

In order to frame a simple contest model, consider a population of $N$ firms, where $n \leq N$ firms are qualified to seek a particular grant. The number $n$ is thus predetermined by the grant-administering agency and can be viewed as the level of a grant's selectiveness. As we will see below, not all of the $n$-qualified firms find it profitable to enter the contest. To 
model the decision to seek a grant, we thus consider the perspective of an entrepreneur (or manager) operating one of the $n$ firms. At a given point in time, each of the $i=1, \ldots, n$ entrepreneurs exerts a unit measure of effort $h_{i} \in[0,1]$ that can be allocated either to producing a final good or to seeking the grant, which include writing applications, conducting lobbying activities, and gathering the information required for the firm to comply with the guidelines established by the governmental agency awarding the subsidy. The remaining effort $1-h_{i}$ given is allocated to productive effort. If $h_{i}=1$, all effort is spent on grant seeking, and if $h_{i}=0$, all effort is spent on a production. Effort, in this setting, comes at no cost without possibility of saving, which means that entrepreneurs will expend all their effort. In the production of the final good, effort is augmented by an entrepreneur-specific and exogenous productivity term $A_{i}$. With a market price of the final good given by $p$, the profit from productive effort earned by entrepreneur $j$ is described as follows:

$$
\Pi_{j}^{P}\left(h_{j}\right)=p A_{j}\left(1-h_{j}\right) .
$$

There are no conditions, such as fatigue, that could cause the profit to decrease as a result of expending additional effort, nor does the entrepreneur employ other factors in producing the good. Of course, these are simplifications, but they are plausible for small firms, at least in the short run. Many small firms have few employees and little physical capital and these factors are likely to be more or less fixed. ${ }^{3}$ Given the productivity term $A_{i}$, which embodies entrepreneurial human capital, the incentives for allocating effort to production depend on the expected profits that could be earned from allocating effort to grant seeking instead of production.

The incentives for seeking grants or subsidies are traditionally modeled using some form of contest function, where contestants expend a certain amount of effort to compete for a monetary prize, here given by $\mu$. The probability of a risk-neutral entrepreneur $j$ winning the contest and acquiring the grant is here given by $P_{j}(\boldsymbol{h})=h_{j} / \sum_{i=1}^{n} h_{i}$. The probability of winning is increasing with $h_{j}$ and decreasing in the efforts expended by the other contestants through $\sum_{i=1}^{n} h_{i}$. The governmental agency administering the contest is thus passive in the sense that the grant is awarded randomly among the entrepreneurs entering the contest, with no regard for the distribution of $A_{i}$. As for the standard contest model, the focus of this paper is not to model the behavior of government agencies but instead that of the entrepreneurs who adapt to existing institutions. As previously mentioned, however, this assumption does not prohibit the government from considering the distribution of $A_{i}$ when deciding the number of $n$ entrepreneurs that are eligible for the contest. Moreover, even if the government would have certain preferences, a random allocation may still serve as a reasonable approximation if these remain largely unknown by the grant-seeking entrepreneurs.

For entrepreneur $j$, the expected profits from grant seeking is given by

$$
\Pi_{j}^{R}(\boldsymbol{h})=\mu \frac{h_{j}}{\sum_{i=1}^{n} h_{i}} .
$$

While productive capacity differs among entrepreneurs, they share the same constant returns technology. With complete information about the distribution of $A$, the problem faced by each entrepreneur is to determine how much effort to expend on production and grantseeking. For entrepreneur $j$, this means finding the level of effort $0 \leq h_{j}^{*} \leq 1$ that

\footnotetext{
${ }^{3}$ In this setting, additional factors would affect the output (profits) only by shifting the productivity term $A_{i}$. To keep the model analytically tractable, we dispense with additional structure.
} 
maximizes the expected profits of both $\Pi_{j}^{P}\left(h_{j}\right)$ and $\Pi_{j}^{R}(\boldsymbol{h})$ using the following objective function:

$$
\max _{h_{j}} \Pi_{j}(\boldsymbol{h})=A_{j}\left(1-h_{j}\right)+\mu^{\prime} \frac{h_{j}}{\sum_{i=1}^{n} h_{i}} .
$$

The price of the final good has been normalized to one, and the cost of grant seeking is expressed as the relative price of $\mu^{\prime}=\mu / p .^{4}$

To solve the full model under the budget constraint that $0<h_{i} \leq 1$, we would need to consider a budget-constrained version of the Tullock model (Che and Gale 1997). However, the possibility that some entrepreneurs would be willing to expend more than their total effort $\left(h_{i}>1\right)$ presents several additional difficulties in solving the model. To keep the model tractable, we restrict the ensuing analysis to contests where the budget constraints are non-binding for all entrepreneurs that enter the contest. ${ }^{5}$ With the caveat that the some of the results presented below may be different in the budget-constrained version of the model, we next proceed to solve the restricted model.

Differentiating (3) with respect to $h_{j}$, results in $n$ separate first-order conditions. For the $j$-th entrepreneur, the marginal revenue of grant seeking equals the marginal revenue of production, where effort is given by

$$
h_{j}=\sum_{i=1}^{n} h_{i}\left(1-\frac{A_{j}}{\mu^{\prime}} \sum_{i=1}^{n} h_{i}\right),
$$

where the expression in brackets corresponds to the winning probability, denoted by $P_{j}(\mathbf{h})$. Without loss of generality, we can order the $n$ entrepreneurs in terms of their productivity, such that $A_{1} \leq A_{2} \leq, \ldots, \leq A_{n}$. The fact that $h_{i}$ is weakly decreasing in $A_{i}$ across all players, $h_{i} \geq 0$ means that there exists an upper bound to $A_{i}$, above which the expected profits from rent-seeking turns negative. This leads to our first result of a participation constraint.

Result 1 (Participation constraint) There exists an upper bound to productivity $\left(A_{i}\right)$ such that all entrepreneurs with a higher productivity will abstain from entering the contest.

These high productive entrepreneurs thus maximize profits by allocating all their effort to production. To incorporate this feature into the model, simply define an integer valued parameter $k \leq n$ that is endogenous to the contest, such that entrepreneurs indexed $i=$

\footnotetext{
${ }^{4}$ In this setting, all contestants operate in the same market and produce the same good with a single price. The model can be extended to one in which the contestants produce heterogeneous goods for different markets. In this case, the relative price becomes entrepreneur-specific, i.e., $\mu_{j}$ for the $j$-th entrepreneur. One interpretation of $\mu_{i}$ is pursued by Stein (2002), with contestants having different valuations of the price. Solving the model with $\mu_{j}$ instead of $\mu$, however, does not fundamentally alter the solution. Another possible extension is to consider a so-called matching grant, where the winner of the contest is required to match the received grant with his or her own funds (Klette and Møen 2012). One way to account for this situation is to add a fixed-cost term $-s \mu^{\prime} P_{j}(\boldsymbol{h})$ to the expression in (2) that is paid in the case of winning, where $s \mu^{\prime}$ is the fraction of the relative price that the winner must match. The inclusion of such a fixed cost does not alter the solution in any significant way, but it does lower the prize to $\mu^{\prime}(1-s)$ and thus decreases the overall grant outlay.

${ }^{5}$ In fact, Yamazaki (2008) highlights that this assumption had been made implicitly by virtually all previous work to that point, with the one exception of Che and Gale (1997). In more recent studies, however, the budget constraints have been modeled explicitly. See, for example, Grossmann and Dietl (2012).
} 


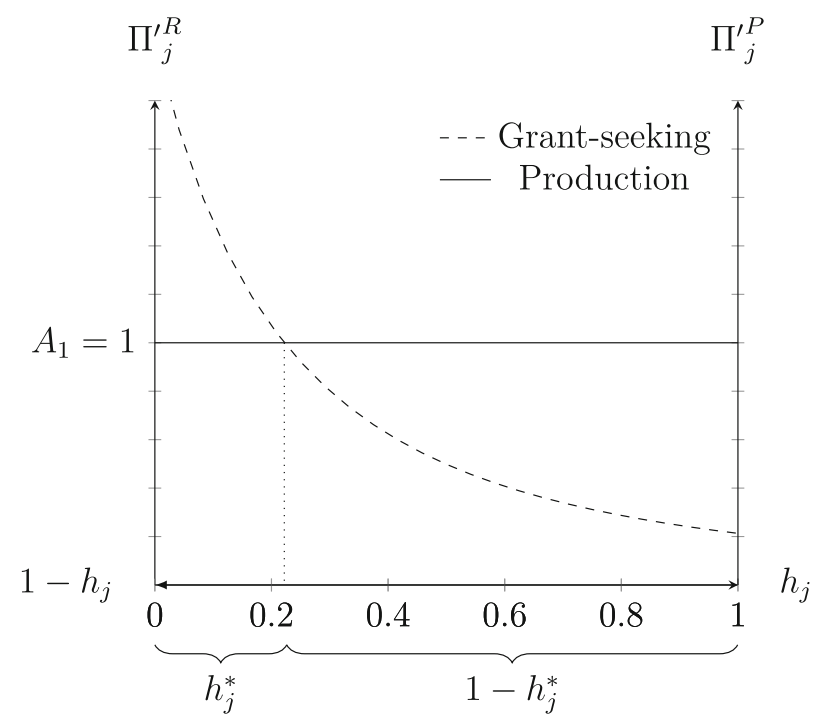

Fig. 1 The allocation of entrepreneurial effort between productive activity and grant seeking

$1, \ldots, k$ enter the contest, and entrepreneurs indexed $i=k+1, \ldots n$ use all their effort for production. $^{6}$

To solve the model, we sum (4) over the $i=1, \ldots, k$ entrepreneurs, which gives the following expression for equilibrium expenditures

$$
\sum_{i=1}^{k} h_{i}^{*}=\frac{\mu^{\prime}(k-1)}{\sum_{i=1}^{k} A_{i}} .
$$

Together, the expressions in Eqs. 4 and 5 fully characterize the equilibrium. The winning probability $P_{j}\left(\mathbf{h}^{*}\right) \equiv h_{j} * / \sum_{i=1}^{k} h_{i}^{*}$ is here given by

$$
P_{j}\left(\mathbf{h}^{*}\right)=1-\frac{A_{j}(k-1)}{\sum_{i=1}^{k} A_{i}} .
$$

Thus, the probability of winning does not depend on the size of the grant $\left(\mu^{\prime}\right)$, but it is a function of the number of players and their respective productivity. Using this expression, we can compare the winning probabilities between different entrepreneurs, which leads to our second result that

Result 2 (Probability sorting) For any two contesting entrepreneurs, the winning probability is higher for the less productive entrepreneur.

Using simple algebra, it is clear that $P_{i}\left(\mathbf{h}^{*}\right)>P_{j}\left(\mathbf{h}^{*}\right)$ if and only if $A_{i}<A_{j}$.

We can illustrate the equilibrium for a given entrepreneur in Fig. 1 that plots the marginal profit from grant seeking (left vertical axis) and production (right vertical axis).

\footnotetext{
${ }^{6}$ By using Proposition 1 in Stein (2002), it is not difficult to derive an expression to find the value of $k$ but for our purposes here it is not central.
} 
Beginning with grant seeking (dashed line), if $h_{j}=0$, the entrepreneur allocates no effort to seeking grants. Since $\Pi_{j}^{\prime R}(0)>\Pi_{j}^{\prime P}(0)$, she can increase the expected profit by increasing $h_{j}$. At some point, however, the dashed line will cross the constant (drawn) line, equating the marginal profits from grant seeking and production. Since no further adjustments can increase profits, it defines the optimal allocations $h_{j}^{*}$ and $1-h_{j}^{*}$. Using specific values of the contest parameters (e.g., $\mu=1, A_{1}=1, A_{i+1}=0.1+A_{i}$, and $k=5$ ), the optimal allocations for entrepreneur $i=1$ would, e.g., correspond to $h_{1}^{*}=0.22$ and $1-h_{j}^{*}=0.78 .^{7}$ From the figure, it is clear that for any other contesting entrepreneur with $A_{i}>A_{1}$, the effort allocated to grant seeking and by implication, also the probability of wining, is lower.

So far, we have not made any assumption that winning (or loosing) the contest could affect the $n$ entrepreneurs. To inquire into the selection of entrepreneurs seeking multiple subsequent grants, we need to account for the period after the contest. Beginning with the case of no effect on productivity from receiving grant, then there is no reason to believe that selection into future contests would be any different.

In reality, however, winning a contest would enable the entrepreneur to, e.g., invest in more $\mathrm{R} \& \mathrm{D}$, which in turn could increase productivity going forward. In this case, the implications for a future contests can be inferred from Eq. 6 using comparative statics, by considering the change in $A_{j}$ as the result from entrepreneur $j$ winning a previous contest. Specifically ${ }^{8}$, from

$$
\frac{\partial P_{j}\left(h_{j}^{*}\right)}{\partial A_{j}}=-\frac{(k-1) \sum_{i \neq j}^{k} A_{j}}{\left(\sum_{i=1}^{k} A_{i}\right)^{2}}<0 \text { and } \frac{\partial P_{i}\left(h_{i}^{*}\right)}{\partial A_{j}}=\frac{(k-1) A_{i}}{\left(\sum_{i=1}^{k} A_{i}\right)^{2}}>0,
$$

we reach the following result.

Result 3 (Comparative statics) An increase in the productivity of one of the $n$ entrepreneurs lowers the probability of winning for that entrepreneur, but increases the probability of winning for all other entrepreneurs.

Thus, given that winning the price increases one's subsequent productivity, previous winners (losers) are less (more) likely than they were to select into seeking additional grants - both in terms of participation and in the probability of winning. However, since the initial order of the entrepreneurs (in terms of productivity) may change after the contest, it is possible that different low-productive entrepreneurs select into the seeking of additional grants. The results hence refer to an increase/decrease in the winning probability conditional on past winning probability. One prerequisite, however, for this interpretation to be valid, is that no other factors confound the distribution of productivity in between contests. ${ }^{9}$

We can summarize the findings by presenting two hypotheses. To conform with the data, the reasoning here is applied to firms instead of entrepreneurs. Based on the results for the participation constraint and probability sorting (results 1 and 2), low-productive firms are expected to have lower opportunity costs in grant seeking. Therefore, we hypothesize (I)

\footnotetext{
${ }^{7}$ Due to the participation constraint, none of the $k$ entrepreneurs who enter the contest face a marginal profit line from production that lies strictly above the intercept of the profit line for grant seeking.

${ }^{8}$ Provided $k \geq 2$ is held fixed.

${ }^{9}$ Since comparative statics describe the directional effect for an instantaneous change, any inference about long-term effects is likely to be strenuous.
} 
that there is a negative relationship between productivity and the probability of receiving a single grant.

For already supported firms, we theorized from the comparative static result (result 3) that the probability of receiving an additional grant hinged on the existence of a lingering effect on productivity from receiving a previous grant. With a static model, we can only say so much about the hypothesized selection into seeking additional grants. In Appendix A, we do consider a dynamic extension of the model with two periods, allowing entrepreneurs to adjust their allocated effort to their expected productivity and hence profit in the period after the contest. While certain aspects of the equilibrium is different, we find that the above results still stand, which leaves us with (II) a non-directional hypothesis about the relationship between productivity and multiple-supported firms.

\section{Data and Description}

To analyze the selection process of firms seeking and eventually receiving grants, we use data from a database provided by the Growth Analysis, which collects information on grants from several agencies in Sweden. It includes information on the size and timing of the grant that we use to construct our dependent variables in the analysis. The data also include a unique firm identifier that enables us to match the grant data with an employer-employee dataset from Statistics Sweden (SCB). The information on grants covers the period between 1997 and 2013 and includes grants from the Swedish Innovation Agency (Vinnova), Swedish Energy Agency (SEA), and Swedish Agency for Economic and Regional Growth (SAERG). These are the three largest grant-administering agencies in Sweden, which means that our sample covers a large share of all selective grants given to firms during the period (OECD 2016). All three agencies seek firms with high growth potential and business ideas that can be scaled-up, rather than mediocre firms in need of additional funding. They can therefore be said to be engaging in "picking winners," rather than financing the marginal entrepreneur in the way suggested by, e.g., Hall (2002).

It is estimated that $3.1 \%$ of the Swedish governmental budget in 2011 was allocated to selective policies targeting innovation, trade, and industry-related objectives to SMEs (Tillväxtanalys 2015). While our lack of access to data on all other grants and subsidies is a shortcoming, we nevertheless have an ample data set.

Different agencies have different objectives for their grants and subsidies. SAERG promotes entrepreneurship in general and is the main provider of EU-based regional subsidies. ${ }^{10}$ The aim of SAERG is to increase firm growth by assisting with funding, network opportunities, and information. Firms can therefore apply for subsidies if they want to invest in physical assets such as machinery or real estate, to purchase business consulting services, to start up co-operation projects with other firms as well as smaller subsidies for entrepreneur's that wish to start a new firm. The EU is a large provider of public subsidies, but their efficiency is debated (see, e.g., Buigues and Sekkat (2011) for an overview the EUs firm subsidy policy). Vinnova focuses on projects related to innovation and R\&D that could be classified as more high-risk and high-tech. ${ }^{11}$ Like SAERG, Vinnova also provides direct funding to firms, but they to a larger extent seek to foster innovation and the creation of new technologies rather than growth per se. Their funds are therefore more project based than,

\footnotetext{
${ }^{10}$ For further information, see their homepage.

${ }^{11}$ For further information, see their homepage.
} 
Table 1 Descriptive statistics of grants and subsidized firms

\begin{tabular}{lllll}
\hline Type of grants & $\begin{array}{l}\text { Innovation } \\
(1)\end{array}$ & $\begin{array}{l}\text { Regional } \\
(2)\end{array}$ & $\begin{array}{l}\text { Energy } \\
(3)\end{array}$ & $\begin{array}{l}\text { Total } \\
(4)\end{array}$ \\
\hline $\begin{array}{l}\text { Number of single grants } \\
\text { Number of multiple grants }\end{array}$ & 1520 & 8939 & 122 & 10,581 \\
$\begin{array}{l}\text { Innovation } \\
\text { Regional }\end{array}$ & 701 & 554 & 162 & 1417 \\
$\begin{array}{l}\text { Energy } \\
\text { Total }\end{array}$ & 2147 & 12,566 & 364 & 14,205 \\
\hline
\end{tabular}

e.g., SAERG, with competition for firms to apply for partly funding of their new research and innovation project. Vinnova seldom finances the entire project and expects the firm to share some of the risk involved. The money can be used for both investments in physical asses as well as paying for wages for, e.g., R\&D personnel.

SEA focuses on projects in the energy sector, with a focus on energy reduction and technological development, such as innovation for reduced energy consumption. ${ }^{12}$ Firms can apply for money for mapping their energy consumption and if possible receive money for investments that will lower their dependence on energy as well as making their energy usage produce less greenhouse gases. Subsidies to energy specific R\&D have proven effective in the USA (Howell 2017), but there is a lack of Swedish studies on SEA's efficiency.

In general, there is a lack of coordination among the different agencies. A firm that has been given a grant by one of these agencies can also secure grants from other agencies without the agencies being aware of this. For firms to comply with the EU de minimis grant rules, it is the firms' duty to report previous supports that they have received and not the agency that administers the grant. This creates opportunities for firms to gain multiple subsides without the knowledge of the other granting agencies, which has been criticized by the Swedish National Audit Office (Riksrevisionen 2016).

Although the goals for the agencies to some extent overlap with the agencies funding similar projects, we can use the separate profiles of the agencies to form a broad typology of grants, referring to the grants awarded by Vinnova as innovation grants, by SAERG as regional grants, and by SEA as energy grants. In Table 1, we present a summary of the distribution of grants by type, distinguishing between the number of grants that go to a single firm (single grants) and grants that go to more than one firm (multiple grants).

In the table, we observe that SAERG is responsible for the largest share of both single and multiple grants, followed by Vinnova and SEA. In total, 14,205 Swedish firms received at least one subsidy at some time in the period considered, of which 3624 firms were granted two or more grants. In the main analysis, we combine the data from all three agencies. However, because the specifics of each grant differ in the criteria for which firms and projects are qualified to apply, in the size of the grant and in the purpose of the grant, we also run separate analyses using grants from each agency in the robustness section of the paper. In Table 2, we present a frequency table over the total number of grants a firm receives during the period. Clearly, most firms receive either one or two grants, but a handful of firms receive more than 10 grants. The highest number of grants received by a single firm is 38 .

\footnotetext{
${ }^{12}$ For further information, see their homepage.
} 
Table 2 Description of the maximum number of grants received by a single firm

\begin{tabular}{|c|c|c|}
\hline Number of supports & Observations & Frequency \\
\hline 1 & 122,013 & 72 \\
\hline 2 & 31,825 & 19 \\
\hline 3 & 8881 & 5.3 \\
\hline 4 & 2603 & 1.5 \\
\hline 5 & 1438 & 0.85 \\
\hline 6 & 562 & 0.33 \\
\hline 7 & 266 & 0.16 \\
\hline 8 & 316 & 0.19 \\
\hline 9 & 31 & 0.018 \\
\hline 10 & 50 & 0.03 \\
\hline 11 & 91 & 0.054 \\
\hline 12 & 30 & 0.018 \\
\hline 13 & 39 & 0.023 \\
\hline 14 & 32 & 0.019 \\
\hline 15 & 26 & 0.015 \\
\hline 16 & 17 & 0.01 \\
\hline 17 & 17 & 0.01 \\
\hline 21 & 15 & 0.0089 \\
\hline 22 & 17 & 0.01 \\
\hline 24 & 45 & 0.027 \\
\hline 25 & 30 & 0.018 \\
\hline 27 & 17 & 0.01 \\
\hline 30 & 17 & 0.01 \\
\hline 32 & 17 & 0.01 \\
\hline 33 & 17 & 0.01 \\
\hline 38 & 13 & 0.0077 \\
\hline Total & 168,425 & 100 \\
\hline
\end{tabular}

Note: The maximum number of supports a firm will receive during the panel. Observations refer to the total number of firm year for the recipients of the corresponding maximum number of grants. Firms that never receives a grant are not included.

The firm-level data comes from SCB and provides us with variables such as sales, value added, investments, capital stock, equity, and educational attainment of the labor force for all firms in Sweden, regardless of their size or legal status.

In the ensuing analysis, our ambition is to extract relevant firm characteristics for the grant-seeking process. To accomplish this goal, we need information about the firms that did not decide to seek a grant. The set of non-supported firms is several magnitudes larger than the set of subsidized firms and contains a great deal of noise that may obfuscate the analysis. To address some of this noise, we impose a number of restrictions on the included firms. First, it is well known that the smallest firms are volatile, and after examining the data, we find that many of these firms lack information on several of the core variables used in the analysis. However, as many grant-seeking firms are small and relatively young, we do not want to exclude too many of these firms, lest we risk skewing the size distribution of non-supported firms beyond that of the subsidized firms. We therefore adopt a conservative cut-off and drop only firms with zero or one employee, regardless of their level of sales. Second, the analyzed grants typically target private service and manufacturing firms that 
are not active in the primary or public sectors. Therefore, firms with a NACE code related to agriculture, restaurants, and publicly funded industries were excluded. ${ }^{13}$ This leaves us with a panel covering both service and manufacturing firms. For a description of the industry distribution, and the regional dispersion of the included firms, see Figs. 3 and 4 in the Appendix. As seen in these figures, the industry and regional distribution of firms that receive subsidies and firms in the control group are rather similar.

Our main focus is on how firm-level productivity relates to the process of receiving grants. Because we do not observe entrepreneurial productivity in the data, as suggested by the theoretical model, we need to find a proxy for this variable. Here, we use (log) labor productivity, as calculated by the value added per employee. ${ }^{14}$ Although it does not capture the aspects of productivity that come from physical capital in production, labor productivity is relatively simple to calculate. In addition to labor productivity, each of the econometric models are fitted using the (log) average wage cost in place of the labor productivity variable, representing the cost side of the firm. This step accomplishes two things: first, it offers an alternative measure of labor productivity and can thus be seen as a robustness test. Second, under the assumption that workers are paid according to their marginal product, the resulting estimates should coincide. Hence, by studying both variables, we can assess the extent to which there is a discrepancy between wages and the marginal product of labor, which otherwise should coincide if wage reflect marginal productivity. We chose not to enter both variables into the same regression, since this would alter the interpretation of labor productivity to that of the gross operating surplus.

In both models, we use additional variables to control for the remaining differences between subsidized and non-subsidized firms that could factor into the selection process. These are the (log) number of employees and the $(\log )$ number of employees squared; the share of skilled workers as a percentage share of the number of workers with post-secondary education; and the firm's equity ratio; together with a set of industry (1 digit), regional controls (NUTS2) as well as year dummies; and firm age. We expect that larger firms will be more likely to receive subsidies because there might be benefits of scale in the application process. For example, a larger firm might have one dedicated employee who completes applications, which a smaller firm could not afford. The equity ratio of the firm is a measure of the firm's financial situation and is defined as capital stock divided by the capital stock plus the firm's short- and long-run debt. As the equity ratio decreases, the firm's indebtedness increases, which might indicate financial difficulties. The skill intensity of the firm controls for human capital in the firm. In addition, skill-intensive firms with a relatively high administrative capacity might be better equipped than other firms to handle this type of task as well as producing projects that the granting agencies deems to be worthwhile. As regards firm age, we control for the fact that younger firms have a higher growth potential and are also typically more credit constrained (Carreira and Silva 2010), which in turn could force them to resort to public subsidies to a larger extent than older firms.

In Table 3, we present the descriptive statistics for all the variables included in the empirical analysis. ${ }^{15} \mathrm{We}$ can see that the number of observations for never-subsidized firms far exceed those for single- and multiple-supported firms. This finding is to be expected because only a total of 14,205 firms received at least one grant at some time during the period. Regarding the data for our key variables labor productivity and labor cost, we note

\footnotetext{
${ }^{13}$ Specifically, firms related to NACE (rev.1) codes 1-5, 55, and 75-99 were excluded.

${ }^{14}$ The value of the labor productivity is calculated by SCB.

${ }^{15}$ Descriptive statistics for firms divided by type of grant (agency) are available from the authors upon request.
} 
Table 3 Summary statistics of explanatory variables

\begin{tabular}{|c|c|c|c|c|c|c|}
\hline & Observations & Mean & Median & Std. Dev. & Min & $\operatorname{Max}$ \\
\hline \multicolumn{7}{|l|}{ Never subsidized } \\
\hline Number of employees & $3,323,489$ & 7.7 & 2 & 76.4 & 0 & 33,644 \\
\hline Average wage cost & $2,766,648$ & 218 & 210 & 181 & 0 & 82,358 \\
\hline Share of skilled workers & $2,597,834$ & 24 & 0 & 34.2 & 0 & 100 \\
\hline Equity ratio & $3,308,985$ & -0.094 & 0 & 101 & $-168,082$ & 1961 \\
\hline Labor productivity & $2,766,648$ & 456 & 366 & 3667 & $-350,605$ & $4,003,316$ \\
\hline Firm age & $2,604,536$ & 6.7 & 4 & 6.7 & 0 & 27 \\
\hline \multicolumn{7}{|l|}{ Single subsidized } \\
\hline Number of employees & 122,013 & 27 & 4 & 242 & 0 & 23,321 \\
\hline Wage costs per employee & 107,904 & 240 & 228 & 983 & 0 & 311,528 \\
\hline Share of skilled workers & 104,102 & 26 & 12 & 32.6 & 0 & 100 \\
\hline Equity ratio & 121,804 & 0.1 & 0 & 9.9 & -1637 & 224 \\
\hline Labor productivity & 107,904 & 452 & 391 & 2102 & $-32,871$ & 610,354 \\
\hline Firm age & 104,157 & 7.7 & 6 & 7.13 & 0 & 27 \\
\hline \multicolumn{7}{|l|}{ Multiple subsidized } \\
\hline Number of employees & 46,412 & 111 & 9 & 699 & 0 & 20,492 \\
\hline Wage costs per employee & 42,946 & 268 & 247 & 203 & 0 & 12,605 \\
\hline Share of skilled workers & 41,885 & 34 & 19 & 34.7 & 0 & 100 \\
\hline Equity ratio & 46,382 & 0.21 & 0 & 4.78 & -674 & 293 \\
\hline Labor productivity & 42,946 & 464 & 418 & 1379 & $-18,784$ & 180,832 \\
\hline Firm age & 41,895 & 8.4 & 7 & 7.38 & 0 & 27 \\
\hline
\end{tabular}

Note: Summary statistics for subsidized and non-subsidized firms for 1997-2013. Observations are firm year, wages, equity ratio, and labor productivity are in real 1000:s SEK

that labor productivity, on average, decreases slightly as we move from never-subsidized firms (456) to single-subsidized (452) and then increases in multiple-subsidized firms (464). For labor costs, we observe an increasing trend of 218, 240, and 268 for the respective categories of firms. These observations contradict our hypothesis of labor productivity being negatively associated with receiving an additional grant. However, these figures are unconditional, so to test the hypotheses, we formulate an econometric model in the next section. Looking instead at the control variables, several interesting patterns can be noticed. We see that multiple-subsidized firms are larger, with 111 employees on average, compared with 27 and 7.7 for single-subsidized and never-subsidized firms, respectively, which could account for some of the trends observed for labor productivity and labor cost. The distribution of firm size is however quite skewed, with much lower median than mean values. Finally, we observe the highest equity ratio and share of workers with a post-secondary education among the multiple-subsidized firms. While most Swedish subsidies are targeted to SMEs, as is apparent from the descriptive statistics, larger firms can get access to subsidies as well.

\section{Empirical Method}

To analyze the selection process into seeking and receiving grants, we estimate a number of discrete and count regression models. While this method does not provide conclusive 
evidence of subsidy entrepreneurship, it can nonetheless indicate whether firms are behaving in line with the theory. We begin by estimating a binary model of the probability of receiving a grant, conditional on firm-level control variables $X_{i, t-1}$, i.e., $P\left(T_{i t}=1 \mid X_{i, t-1}\right)$, where $T_{i t}$ takes a value of 1 if firm $i$ receives a grant at time $t, 0$ otherwise. In those cases where the subsidy is paid out over several years, we use the first observation to create this binary variable. Since our objective is to analyze the self-selection of firms into grants, rather than the treatment effect of the grants, we abstain from using matching and differencein-difference methods. To estimate the relationship between the categorical variable $T_{i t}$ and explanatory variables $X_{i, t-1}$, we use logistic regressions. To avoid post-treatment bias, we only use observations on the treated firms up until they receive their first subsidy.

In the first model, we consider the probability of receiving a grant, not separating single- from multiple-subsidized firms. To analyze potential differences between singleand multiple-subsidized firms, we next split the sample by running a separate regression for single- and multiple-subsidized firms. This division is motivated by the expectation that multiple-supported firms are more likely to specialize and divert more effort into seeking grants than are firms that received merely a single grant. We further test this difference between single- and multiple-supported firms using ordered logistic regressions.

To estimate the relationship between the number of support $N_{i t}$ and $X_{i, t-1}$, we turn to count data models. Since the assumption required for Poisson regression is not met, we use negative binomial (NB) regression for this purpose. ${ }^{16}$ In each of the models, we include fixed effects at the levels of regions, industries, and years.

Finally, since the probability of receiving support can be dependent on previous grant seeking experience according to both theory and previous empirical evidence, we also test the model with a dynamic probit regression with a lagged dependent variable to address this potential source of endogentiy (Wooldridge 2005; Akay 2012). Following Wooldridge (2005), the dynamic model is estimated on the full panel using random effects at the firm level.

\section{Results}

We start the analysis in Table 4 where all supported firms are compared against the population of non-supported firms. The results suggest that productivity is negatively related to the probability of receiving a grant. This result is in line with the theoretical prediction, suggesting that low-productivity firms have a low opportunity cost of seeking subsidies, which would mean that they spend relatively more resources on seeking grants and therefore become over-represented in the grant statistics.

Seeking subsidies is not necessarily a simple process, where firms seek subsidies in competition with other firms. For instance, the ability to write an application or to design a project that the granting agency considers worthwhile can be instrumental for acquiring a subsidy. It is therefore reasonable to presume that the quality of the application and the quality of the project are positively correlated with the educational attainment of the employees. In line with this argument, the results further suggest that firms with a relatively large share

\footnotetext{
${ }^{16}$ The large number of observations with no subsidies means that a zero-inflated NB regression could also be used. However, we choose not use such a regression due to convergence difficulties using the zero-inflated negative binomial estimator.
} 
Table 4 Logit regressions. Supported and non-supported firms

Standard errors in parentheses with significance levels given by $* p<0.1, * * p<0.05$, and $* * * p<0.01$. Dependent variable: dummy variable for subsidized and non-subsidized firms. Only the first observation of subsidized firms is utilized. Cluster robust s.e. at the firm level. All explanatory variables except firm age lagged one year. Year, regional, and industry-fixed effects

\begin{tabular}{|c|c|c|}
\hline & Full sample & Full sample \\
\hline Number of employees (log) & $\begin{array}{l}0.57 * * * \\
(0.024)\end{array}$ & $\begin{array}{l}0.57 * * * \\
(0.025)\end{array}$ \\
\hline Number of employees squared (log) & $\begin{array}{l}-0.028 * * * \\
(0.0048)\end{array}$ & $\begin{array}{l}-0.027 * * * \\
(0.0048)\end{array}$ \\
\hline Average wage cost (log) & $\begin{array}{l}0.0029 \\
(0.017)\end{array}$ & \\
\hline Share of skilled workers & $\begin{array}{l}0.0094 * * * \\
(0.00037)\end{array}$ & $\begin{array}{l}0.0090 * * * \\
(0.00038)\end{array}$ \\
\hline Equity ratio & $\begin{array}{l}-0.00032 \\
(0.00023)\end{array}$ & $\begin{array}{l}-0.00043^{*} \\
(0.00024)\end{array}$ \\
\hline Firm age & $\begin{array}{l}-0.013 * * * \\
(0.0015)\end{array}$ & $\begin{array}{l}-0.011^{* * * *} \\
(0.0015)\end{array}$ \\
\hline Labor productivity (log) & & $\begin{array}{l}-0.068^{* * * *} \\
(0.014)\end{array}$ \\
\hline Constant & $\begin{array}{l}-5.16^{* * * *} \\
(0.11)\end{array}$ & $\begin{array}{l}-4.81 * * * \\
(0.099)\end{array}$ \\
\hline Observations & $2,153,594$ & $2,117,877$ \\
\hline
\end{tabular}

of workers with higher education are more likely to receive a grant. It thus appears that low productivity and having a well-educated labor force are two factors driving the selection into grants.

Central to our analysis is the comparison between single- and multiple-subsidized firms. As a first step, we present the results in Table 5, where we run separate regressions on multiple-subsidized firms and single-subsidized firms, and where each group is compared with the group of non-subsidized firms. Hence, here we ask if it is possible to distinguish multiple-supported firms based on their prior characteristics.

One way to think of this identification strategy is to envision that the grants have zero or low impact on firm productivity, and that productivity growth in general have the same pattern among treated and non-treated firms. If this is the case, low-productivity firms are less likely to reach the upper threshold of productivity where it becomes non-profitable to search grants (from result 1 in Section 3), and are thus more likely to show up in future grant races. That is, even without the possibility of learning from previous grants, it makes sense to separate non-, single-, and multiple-supported firms. One may, however, argue that if there is learning from grant seeking and/or uncertainty about a firm's own grantseeking ability, the patterns of repeated grant seeking can be further enhanced. If the cost of searching and applying for grants is decreasing with the number of applications, it could thus lead to a productivity shake-out of the more productive firms, hence further enhancing the probability of already granted firms to acquiring one more grant.

This simple operation reveals several interesting patterns. First, we note from Table 5 that the result for labor productivity and share of skilled workers are negative and strongly significant for both multiple-subsidized firms and single-subsidized firms. We also note that the relationship is even more negative for multiple-subsidized firms, suggesting that productivity is more strongly associated with selection for this group into grant seeking. 
Table 5 Logit regressions. Single-, multiple- and non-supported firms

\begin{tabular}{|c|c|c|c|c|}
\hline & Single & Multiple & Single & Multiple \\
\hline Number of employees (log) & $\begin{array}{l}0.50 * * * \\
(0.029)\end{array}$ & $\begin{array}{l}1.00 * * * \\
(0.046)\end{array}$ & $\begin{array}{l}0.50 * * * \\
(0.029)\end{array}$ & $\begin{array}{l}1.03 * * * \\
(0.047)\end{array}$ \\
\hline Number of employees squared (log) & $\begin{array}{l}-0.041^{* * *} \\
(0.0060)\end{array}$ & $\begin{array}{l}-0.061 * * * \\
(0.0080)\end{array}$ & $\begin{array}{l}-0.040 * * * \\
(0.0061)\end{array}$ & $\begin{array}{l}-0.063 * * * \\
(0.0083)\end{array}$ \\
\hline Average wage cost $(\log )$ & $\begin{array}{l}-0.039 * * \\
(0.019)\end{array}$ & $\begin{array}{l}0.056^{*} \\
(0.033)\end{array}$ & & \\
\hline Share of skilled workers & $\begin{array}{l}0.0061 * * * \\
(0.00042)\end{array}$ & $\begin{array}{l}0.017 * * * \\
(0.00068)\end{array}$ & $\begin{array}{l}0.0059 * * * \\
(0.00044)\end{array}$ & $\begin{array}{l}0.016^{* * * *} \\
(0.00071)\end{array}$ \\
\hline Equity ratio & $\begin{array}{l}-0.00038 \\
(0.00024)\end{array}$ & $\begin{array}{l}-0.00022 \\
(0.00026)\end{array}$ & $\begin{array}{l}-0.00047 * \\
(0.00025)\end{array}$ & $\begin{array}{l}-0.00039 \\
(0.00025)\end{array}$ \\
\hline Firm age & $\begin{array}{l}-0.0079 * * * \\
(0.0017)\end{array}$ & $\begin{array}{l}-0.021 * * * \\
(0.0025)\end{array}$ & $\begin{array}{l}-0.0067 * * * \\
(0.0017)\end{array}$ & $\begin{array}{l}-0.017 * * * \\
(0.0025)\end{array}$ \\
\hline Labor productivity (log) & & & $\begin{array}{l}-0.058 * * * \\
(0.016)\end{array}$ & $\begin{array}{l}-0.12^{* * *} \\
(0.024)\end{array}$ \\
\hline Constant & $\begin{array}{l}-5.15^{* * *} \\
(0.12)\end{array}$ & $\begin{array}{l}-7.28 * * * \\
(0.19)\end{array}$ & $\begin{array}{l}-5.05^{* * * *} \\
(0.12)\end{array}$ & $\begin{array}{l}-6.40^{* * *} \\
(0.16)\end{array}$ \\
\hline Observations & $2,123,745$ & $2,093,223$ & $2,089,269$ & $2,058,815$ \\
\hline
\end{tabular}

Standard errors in parentheses with significance levels given by $* p<0.1$, ** $p<0.05$, and $* * * p<0.01$. Dependent variable: dummy variable for subsidized and non-subsidized firms. Only the first observation of subsidized firms is utilized. Cluster robust s.e. at the firm level. All explanatory variables except firm age lagged one year. Year, regional, and industry-fixed effects

Note that after controlling for a series of firm characteristics, we have a positive selection of high-wage firms into multiple-subsidized firms whereas the opposite is true for singlesubsidized firms. The relatively high wage among multiple-subsidized firms is somewhat unexpected and counter-intuitive to the low-productivity result, since the former constitutes an alternative measure of the latter. The combination of high wages and low productivity could possibly describe a period of investments and capacity building.

In Table 6, we refine the comparison across groups by estimating an ordered logit model for non-, single-, and multiple-subsidized firms. Overall, the results from Table 5 are maintained. We find that subsidies are related to low productivity, high wages (although not significant), and a skilled workforce.

The number of supports differs widely in our sample. Whereas most of the multipletreated firms receive two subsidies, there is a non-negligible set of firms that receive more than 20 different subsidies. It therefore becomes relevant to disentangle the group of subsidized firms by looking at the actual number of grants received. In Table 7, we separate supported firms by counting the number of grants received and estimating a count data model using a negative binomial (NB) regression framework. It estimate the probability of receiving $1,2, \ldots, N$ grants based on the same firm characteristics and method as given above.

The results from the NB regressions show similar patterns as the initial logit regressions. To be precise, the results from the NB estimations in Table 7 suggest that for an additional grant, there is a significant trend of increasing wages, falling productivity, and a higher share of skilled labor. 
Table 6 Ordered logit regressions

Standard errors in parentheses with significance levels given by ${ }^{*} p<0.1, * * p<0.05$, and $* * * p<0.01$. Dependent variable: dummy variable indicating whether a firm receives zero, a single, or multiple supports. Only the first observation for subsidized firms is utilized. All explanatory variables except firm age lagged one year. Cluster robust s.e. at the firm level. Year, regional, and industry-fixed effects

\begin{tabular}{lll}
\hline & Full sample & Full sample \\
\hline Number of employees $(\log )$ & $0.58 * * *$ & $0.58 * * *$ \\
& $(0.026)$ & $(0.027)$ \\
Number of employees squared $(\log )$ & $-0.024 * * *$ & $-0.024 * * *$ \\
& $(0.0052)$ & $(0.0053)$ \\
Average wage cost $(\log )$ & 0.0031 & \\
Share of skilled workers & $(0.018)$ & \\
Equity ratio & $0.0097 * *$ & $0.0093 * * *$ \\
Firm age & $(0.00037)$ & $(0.00039)$ \\
& -0.00033 & $-0.00044^{*}$ \\
Labor productivity $(\log )$ & $(0.00023)$ & $(0.00024)$ \\
& $-0.013 * * *$ & $-0.011^{* * *}$ \\
& $(0.0015)$ & $(0.0015)$ \\
Observations & & $-0.069 * * *$ \\
\hline
\end{tabular}

Regarding the control variables, we find no striking differences for the equity ratio between the groups. However, we find consistent evidence that both larger, in terms of employees, and younger firms are more likely to receive grants.

Table 7 Results from NB regressions

Standard errors in parentheses with significance levels given by ${ }^{*} p<0.1, * * p<0.05$, and $* * * p<0.01$. Dependent variable: number of cumulative supports a firm receives. All explanatory variables except firm age lagged one year. Robust standard errors. Year, regional, and industry-fixed effects. Reported coefficients are incident odds ratios

\begin{tabular}{|c|c|c|}
\hline & Full sample & Full sample \\
\hline Number of employees (log) & $\begin{array}{l}0.55 * * * \\
(0.0085)\end{array}$ & $\begin{array}{l}0.55 * * * \\
(0.0088)\end{array}$ \\
\hline Number of employees squared (log) & $\begin{array}{l}-0.020 * * * \\
(0.0016)\end{array}$ & $\begin{array}{l}-0.020 * * * \\
(0.0016)\end{array}$ \\
\hline Average wage cost (log) & $\begin{array}{l}0.058 * * * \\
(0.0099)\end{array}$ & \\
\hline Share of skilled workers & $\begin{array}{l}0.011 * * * \\
(0.00015)\end{array}$ & $\begin{array}{l}0.011 * * * \\
(0.00015)\end{array}$ \\
\hline Equity ratio & $\begin{array}{l}-0.00022 \\
(0.00021)\end{array}$ & $\begin{array}{l}-0.00035 \\
(0.00023)\end{array}$ \\
\hline Firm age & $\begin{array}{l}-0.014 * * * \\
(0.00059)\end{array}$ & $\begin{array}{l}-0.011^{* * *} \\
(0.00059)\end{array}$ \\
\hline Labor productivity (log) & & $\begin{array}{l}-0.069 * * * \\
(0.0074)\end{array}$ \\
\hline Constant & $\begin{array}{l}-5.53 * * * \\
(0.057)\end{array}$ & $\begin{array}{l}-4.88 * * * \\
(0.051)\end{array}$ \\
\hline Observations & $2,189,644$ & $2,152,657$ \\
\hline
\end{tabular}


Finally, as a robustness test, we finally estimate a dynamic probit model with random effects, to account for the experience of having received previous grants along with unobserved firm-specific heterogeneity. The results are presented in Table 8, where the dependent variable is a binary variable that takes the value of one for the years that a firm receives a subsidy, and zero for the years that a firm does not receive a subsidy. For instance, a firm that during the observed period receives three subsidies will have three observation points coded as "one" and the remaining observations coded as "zero." We then lag this variable one year and include it in the regressions. Introducing a lagged dependent variable does not upset the previous result of a negative and highly significant productivity parameter. We note that the lagged dependent variable is highly significant and positive, which confirm the previous findings that having received a grant increases the probability of receiving additional future grants.

In summary, after comparing the results across various models, we find that skill intensity tend to increase and productivity decrease with the number of grants received. For wages, however, the results in general suggests that more subsidies increases wages, with the exception of firms that receives only one subsidy. We also emphasize that these findings hold even before the firms have received their first observed grant since the explanatory variables are lagged. Hence, we conclude that it may be possible to identify potential subsidy entrepreneurs at a fairly early stage in the grant-searching process.

\subsection{Robustness Checks}

In this section, we analyze the robustness of the results with respect to the agency administrating the grants (Vinnova and SAERG), alternative productivity measures, firm size, and

Table 8 Results from dynamic probit regressions
Standard errors in parentheses with significance levels given by ${ }^{*} p<0.1, * * p<0.05$, and $* * * p<0.01$. Dependent variable: dummy variable for subsidized and non-subsidized firms for each subsidy. All explanatory variables except firm age lagged one year. Year, regional, and industry-fixed effects. Panel random effects

\begin{tabular}{|c|c|c|}
\hline & Full sample & Full sample \\
\hline Lagged dependent variable & $\begin{array}{l}0.31 * * * \\
(0.020)\end{array}$ & $\begin{array}{l}0.30 * * * \\
(0.021)\end{array}$ \\
\hline Number of employees (log) & $\begin{array}{l}0.19 * * * \\
(0.0084)\end{array}$ & $\begin{array}{l}0.20 * * * \\
(0.0084)\end{array}$ \\
\hline Number of employees squared (log) & $\begin{array}{l}0.00084 \\
(0.0014)\end{array}$ & $\begin{array}{l}-0.00017 \\
(0.0014)\end{array}$ \\
\hline Average wage cost (log) & $\begin{array}{l}0.012 \\
(0.0092)\end{array}$ & \\
\hline Share of skilled workers & $\begin{array}{l}0.0057 * * * \\
(0.00015)\end{array}$ & $\begin{array}{l}0.0055 * * * \\
(0.00015)\end{array}$ \\
\hline Equity ratio & $\begin{array}{l}-0.000054 \\
(0.00090)\end{array}$ & $\begin{array}{l}0.000039 \\
(0.0017)\end{array}$ \\
\hline Firm age & $\begin{array}{l}-0.017^{* * *} \\
(0.00069)\end{array}$ & $\begin{array}{l}-0.016^{* * *} \\
(0.00069)\end{array}$ \\
\hline Labor productivity (log) & & $\begin{array}{l}-0.032 \text { *** } \\
(0.0068)\end{array}$ \\
\hline Constant & $\begin{array}{l}-3.10^{* * *} \\
(0.053)\end{array}$ & $\begin{array}{l}-2.86^{* * * *} \\
(0.047)\end{array}$ \\
\hline Observations & $2,189,644$ & $2,152,657$ \\
\hline
\end{tabular}


Table 9 Summary of robustness checks

\begin{tabular}{|c|c|c|c|}
\hline & Productivity & Wages & Skill intensity \\
\hline Agency - Vinnova & Positive & Positive $* * *$ & Positive $* * *$ \\
\hline Agency - Vinnova - Subsidy receiver & Negative $* * *$ & Positive & Positive*** \\
\hline Agency - SAERG & Negative*** & Negative*** & Positive*** \\
\hline LevPet and Wooldridge productivity & Negative**** & Positive*** & Positive $* * *$ \\
\hline Less than 25 supports & Negative $* * *$ & Positive*** & Positive*** \\
\hline SME:s & Negative $* * *$ & Positive*** & Positive ${ }^{* * *}$ \\
\hline
\end{tabular}

Results based on negative binomial regressions

the removal of firms with the highest number of received grants. The results are summarized in Table 9.

One potential argument against our results is that the aim and purpose of the programs vary across agencies. It might therefore be incorrect to lump them together. Given that Vinnova, to a larger extent than SAERG, seeks to subsidize firms with high innovative capability, the firms that receive subsidies from Vinnova should have higher quality than the firms that receives SAERG subsidies. Separating firms with respect to the granting agency, we find, in line with this hypothesis, a difference across agencies. For SAERG (with a regional focus), we find negative productivity effects, but the opposite is true for Vinnova, where a positive productivity pattern is found. Turning to wages, we instead find negative wage effects of SAEREG, whereas the positive wage effect of Vinnova remains. However, when considering skill intensity, the results are similar across agencies. ${ }^{17}$

Since Vinnova often gives subsidies to firms that collaborate with larger firms, we also rerun the regressions by focusing only on the firms that receive the money and exclude any partnering firm that does not receive any grants. ${ }^{18}$ The removal of partnering firms that does not receive the subsidy changes the results. Productivity estimate then becomes significantly negative, even though Vinnova may attract firms with more growth potential that seek grants for, e.g., R\&D investments.

Moreover, one could question the use of labor productivity as our choice of measures of productivity. We therefore reran the main regressions using two alternative total factor productivity measures, henceforth referred to as LevPet and Wooldridge (Levinsohn and Petrin 2003; Wooldridge 2009; Rovigatti and Mollisi 2016). Since the variables are skewed with outliers, we winzorize the productivity measures at the top $95 \%$ percentile. Changing the productivity measure does not upset the results of a positive relationship with wages and firm skill intensity, and for both new measurements of productivity, we find similar significant negative results as when we used labor productivity.

Our final two robustness checks consider firm size and the number of received grants. A few firms receive a relatively large number of grants and may thus bias the results if these firms are different than the average firm. As a robustness test, we remove firms that have received more than 25 grants from the analysis. Moreover, in many cases, the intention of the programs is to promote growth among SMEs. As a final robustness check, we therefore rerun the analysis for small firms only (firms with fewer than 50 employees) and firms

\footnotetext{
${ }^{17}$ For firms receiving multiple subsidies from SEA, we have too few observations to analyze them separately.

${ }^{18}$ This is exactly the same as our analysis of SAERG subsidies, where we estimate the results based on the firms that are receiving the payment.
} 
receiving at most 25 grants. None of these robustness checks alters the main results. ${ }^{19}$ Subsidized firms can be characterized as having low productivity, high wages, and being skill intensive, and all these characteristics become more pronounced as we move from singleto multiple-subsidized firms. Wages are positive in all regressions but significant only in some. The regression tables of the robustness checks are included in the Appendix.

\section{Discussion and Conclusions}

Solving market failures in capital markets for firms is a difficult task. On one hand, governments might be able to correct the market failure and improve the equilibrium outcome with appropriately targeted subsidies and interventions. On the other hand, there is always a risk that subsidies are targeted toward the wrong firms or may trigger unintended behavior by the firms.

Our aim in this paper is to fill the gap in the research on the strategies for firms that seek selective and publicly sponsored innovation and growth programs, a subject that has received little attention. Firms drawn to grant-seeking activities are here labeled subsidy entrepreneurs, indicating that these firms find it relatively profitable to engage in grantseeking activities compared to market production.

To analyze which firms are drawn to selective innovation and growth-targeted programs, we develop a simple model of grant seeking in which the cost of seeking grants is due to the cost of reallocating labor from productive work to grant seeking. With this setup, the opportunity cost of seeking grants is higher for productive firms than it is for less-productive firms. Hence, unproductive firms will self-select into grant-seeking activities.

Using detailed firm-level data with information on the received grants and firms' input and output, we analyze how firm attributes, such as productivity, wages, and skill intensity, influence a firm's likelihood of being subsidized. Overall, the results suggest that the firms that receive subsidies have low productivity and a large share of workers with higher education. These characteristics are further pronounced when we separate multiple-subsidized firms from single-subsidized firms, with the additional results that multiple-supported firms also have high wages even when controlling for human capital.

The tendency to weed-out high-productivity firms as firms receive an additional grant can be a three-sided process. First, firms that experience high-productivity growth will opt out of future grant seeking, leaving weaker firms to receive future grants. In addition, to the extent that there is a learning process involved in grant seeking, low-productivity firms will allocate more resources to grant seeking. Against these selection mechanism, agencies are most likely more interested in supporting promising firms than the weakest ones. Hence, there are selection forces working in both directions. The results from studying firms presupport characteristics indicate that the impact of high-productivity firms leaving the grantseeking contest and of a bias toward weaker firms specializing in grant-seeking dominates the productivity effect. ${ }^{20}$

Finally, we found a drift toward higher wages among multiple-subsidized firms. In our model, the wage setting process is not further elaborated. A possible explanation for this result is that the grants, to some extent, are treated as a windfall gain, allowing for a bonus

\footnotetext{
${ }^{19}$ The main results still hold when the threshold for outliers is lowered to firms that received more than 5 subsidies.

${ }^{20}$ In this study, we analyze the characteristics of supported firms rather than the strategies used by firms to win the contest. An analysis of the strategies used to win such contests could shed further light on this issue.
} 
when the grant is realized. Our finding that subsidies is related to high wages is in line with Goolsbee (1998) who suggests that subsidies to R\&D increases wages among researches and engineers, although we cannot conclude that this relationship is causal. This issue is, however, not further elaborated here and is left for future research.

While we have evaluated the selection of firms into subsidies, we have not evaluated the causal effect of these subsidies in the long run. This omission is due to both the fact that the issue is beyond the scope of the paper and to practical issues in evaluating multiple treatment effects. Previous Swedish research has both found positive (Söderblom et al. 2015) and non-existent or negative effects (Tillväxtanalys 2014; Gustafsson et al. 2016; Tingvall and Videnord 2018) but has focused primarily on firms that receive a single subsidy. Hopefully, future research might address the effects of multiple subsidies in the long run and therefore conclude if these subsidies are worthwhile from a cost-benefit perspective.

Several conclusions can be drawn based on these results. First, the evidence indicates that there is a certain population of firms that repeatedly receives public innovation and growth-targeted grants. Second, the population of supported firms can be characterized as having low productivity, skill intensive, and in the case of multiple-supported firms, high wages. That is, we cannot reject the hypothesis of the existence of a population of firms that specialize in grant seeking, at the expense of market production. From a public policy perspective, these results suggest that the current way of supporting firms with innovation and growth-targeted grants might be problematic because it can create incentives for firms to become subsidy entrepreneurs, which could be an unproductive form of entrepreneurship (Baumol 1990; Klein et al. 2010).

Acknowledgments We are grateful to Jay Barney, Justus Haucap, Peter G. Klein, Martin Korpi, Johan P. Larsson, Agostino Manduchi, Domenico Viganola, Bengt Söderlund, and Karl Wennberg for providing valuable comments; to Christian Barsom for stellar research assistance; and to seminar participants at the Swedish National Conference in Economics, The Ratio-Bough Colloquium for Young Social Scientists, The Swedish Agency for Growth Policy Analysis, The Research Institute of Industrial Economics (IFN), Jönköping International Business School, Örebro university, and the Ratio Institute for additional comments. We are also grateful to The Swedish Agency for Growth Policy Analysis for generously providing us with data. Financial support from the Swedish Competition Authority, the Swedish Agency for Growth Policy Analysis (Tillväxtanalys) and the Swedish Innovation Agency (Vinnova) is gratefully acknowledged.

Funding information Open access funding provided by Örebro University. This study was financially supported by the Swedish Competition Authority, the Swedish Agency for Growth Policy Analysis (Tillväxtanalys) and the Swedish Innovation Agency (Vinnova).

\section{Appendix}

\section{Appendix A: Extended model with dynamic productivity}

It is possible that winning a contest affects subsequent productivity. To account for this aspect, we consider two periods. In the first, (before the contest) entrepreneurs face the same choice of allocating their effort between production and grant seeking. In making this choice, however, the entrepreneurs now also consider the expected profit from production in a second period (after the contest), where productivity depends on the outcome of the contest. Specifically, if an entrepreneur looses, productivity remains unchanged $\left(A_{j}\right)$, but if she win, it is given by $A_{i}^{\prime}$. Going forward we make the assumption that $A_{j}^{\prime}>A_{j}$. Since the outcome of the contest is uncertain, the expected profit from the second period is given by

$$
\Pi_{2, j}(\mathbf{h})=A_{j}\left[1-P_{j}(\mathbf{h})\right]+A_{j}^{\prime} P_{j}(\mathbf{h}) .
$$




\begin{tabular}{|c|c|c|}
\hline & on or grant-seeking & Production \\
\hline Choose $h$ & Period 1 & Period 2 \\
\hline
\end{tabular}

Fig. 2 Timing of the model

With a probability of $1-P_{j}(\mathbf{h})$, the $j^{\text {th }}$ entrepreneur looses the contest and thus earn a profit of $A_{j}$; with a probability of $P_{j}(\mathbf{h})$, she wins the contest and earns a profit of $A_{j}^{\prime}{ }^{21}$ The overall timing of the model is illustrated in Fig. 2.

If we denote the profit function described in Eq. 3 by $\Pi_{1, j}(\mathbf{h})$, each entrepreneur now chooses $h_{j}$ to maximize $\Pi_{j}(\mathbf{h}) \equiv \Pi_{1, j}(\mathbf{h})+\Pi_{2, j}(\mathbf{h})$, which is a function of $h_{j}$ that is determined solely in the first period, and writes

$$
\max _{h_{j}} \Pi_{j}(\mathbf{h})=A_{j}\left(1-h_{j}\right)+\mu^{\prime} P_{j}(\mathbf{h})+A_{j}\left[1-P_{j}(\mathbf{h})\right]+A_{j}^{\prime} P_{i}(\mathbf{h}) .
$$

For simplicity, we let $A_{j}^{\prime}$ to be a fixed mark-up of $A_{j}$ given by $A_{j}^{\prime}=A_{j}(1+\epsilon)$ where $\epsilon>0$ is the same for all players. The expression then simplifies to

$$
\max _{h_{j}} \Pi_{j}(\mathbf{h})=-A_{j} h_{j}+\left(\mu^{\prime}+A_{j} \epsilon\right) P_{j}(\mathbf{h}) .
$$

Differentiating with the respect to $h_{j}$, the first-order condition along with the resulting aggregate expenditures is here given by,

$$
h_{j}=\sum_{i=1}^{k} h_{i}\left[1-\frac{A_{j}}{\mu^{\prime}+A_{j} \epsilon} \sum_{i=1}^{k} h_{i}\right], \text { where } \sum_{i=1}^{k} h_{i}=\frac{k-1}{\sum_{i=1}^{k} A_{i} /\left(\mu^{\prime}+A_{i} \epsilon\right)} .
$$

Together they define the new equilibrium allocation, where the winning probability for the $j^{\text {th }}$ entrepreneur is given by

$$
P_{j}\left(\mathbf{h}^{*}\right)=1-(k-1) \frac{A_{j} /\left(\mu^{\prime}+A_{j} \epsilon\right)}{\sum_{j=1}^{n} A_{i} /\left(\mu^{\prime}+A_{i} \epsilon\right)} .
$$

Compared with the basic model (with $\epsilon=0$ ), we make the following observations. When entrepreneurs are allowed to be forward looking, $P_{j}\left(\mathbf{h}^{*}\right)$ is no longer independent of the monetary price $\mu$. Yet, from Eq. 11, it follows that the effort allocated to seeking grants $\left(h_{j}^{*}\right)$ is still inversely related to the level of productivity, meaning that high-productivity entrepreneurs still allocate all their effort to production. ${ }^{22}$ Moreover, if $A_{j}$ would increase for the $j^{\text {th }}$ entrepreneur, it is not difficult to show that the winning probability also here decreases

$$
\frac{\partial P_{j}\left(\mathbf{h}^{*}\right)}{\partial A_{j}}=\frac{-\mu^{\prime}(k-1) \sum_{i \neq j}^{n} A_{i} /\left(\mu^{\prime}+A_{i} \epsilon\right)}{\left[\left(\mu^{\prime}+A_{j} \epsilon\right) \sum_{j \neq i}^{n} A_{i} /\left(\mu^{\prime}+A_{i} \epsilon\right) A_{j}+A_{j}\right]^{2}}<0 .
$$

Hence, while certain attributes of the equilibrium are different in the modified model, we conclude that the general mechanisms that characterize the selection process of seeking a grant remains the same.

\footnotetext{
${ }^{21}$ While the expected profits earned in the second period should be properly discounted, we opt for not including a discounting factor, which can be absorbed into the mark-up term $\epsilon$ (defined below) in equilibrium. ${ }^{22}$ The number of participants $k$ can differ between the models, and therefore also the designation of entrepreneurs as "high productive". Here, participation depends on both $\mu$ and $\epsilon$ and further requires that $\epsilon<\sum_{i=1}^{k} h_{i}$.
} 

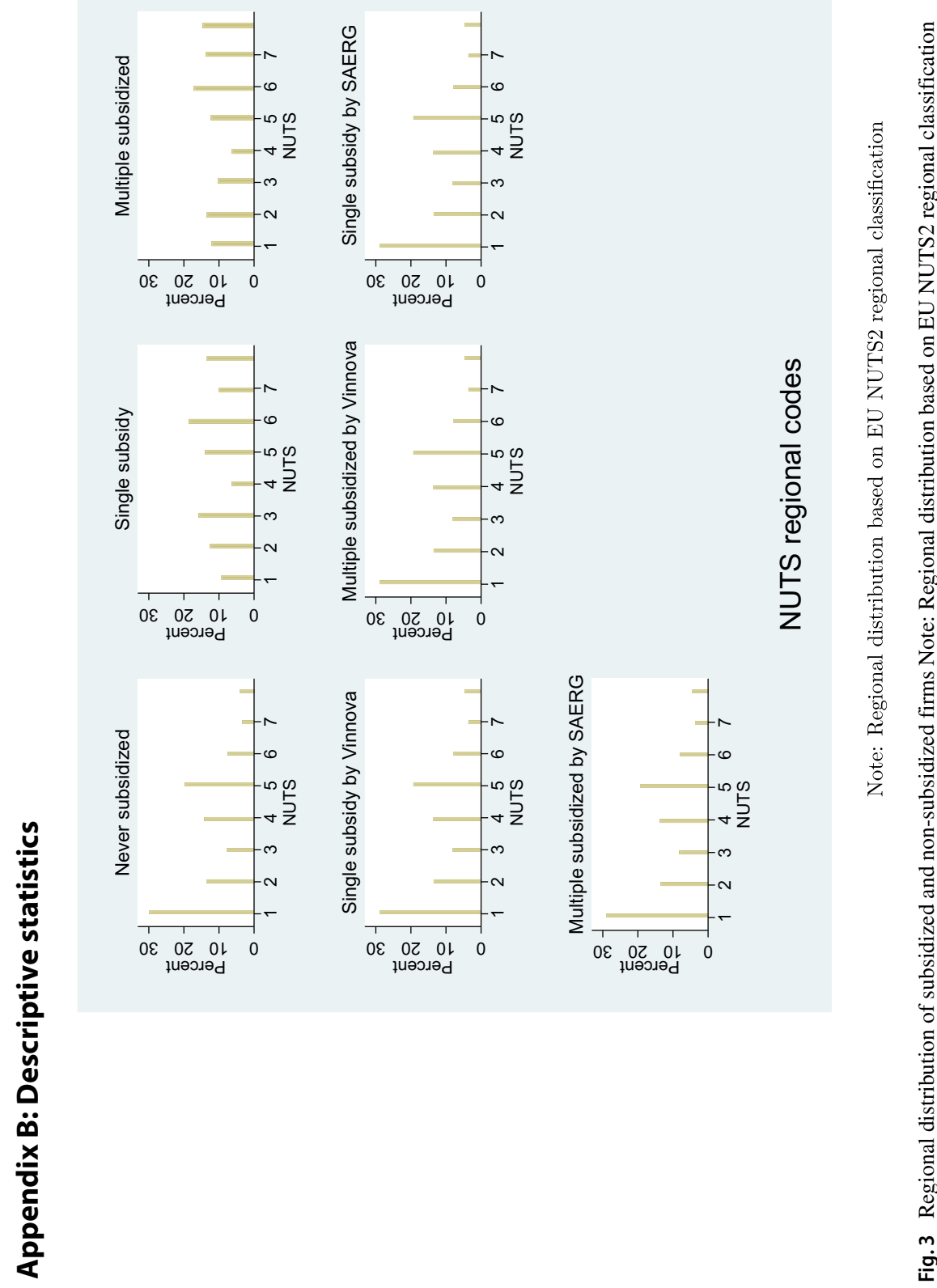

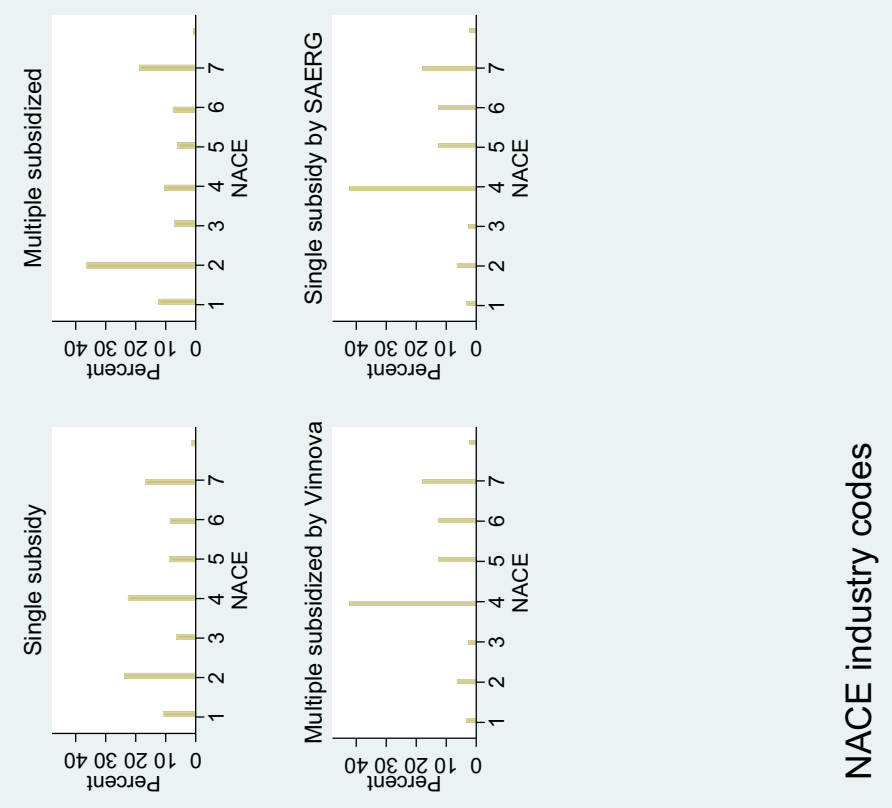


\section{Appendix C: Robustness regressions}

In the following section, we present all robustness results that were briefly described in Table 9. In the following order, we test:

1. Only innovation subsidies from Vinnova.

2. Only the firm that receives the Vinnova innovation subsidy rather than co-operating firms.

3. Only regional subsidies from SAERG.

4. Use total factor productivity as dependent variable rather than labor productivity.

5. Remove firms with more than 25 supports.

6. Remove firms with more than 250 employees.

The conclusions that firms that receive many subsidies have high wages and low productivity remains significant.

\section{C.1 Only Vinnova regressions}

Table 10 Results from logit regressions

Standard errors in parentheses with significance levels given by ${ }^{*} p<0.1, * * p<0.05$, and $* * * p<0.01$. Dependent variable: dummy variable for subsidized and non-subsidized firms. Only the first observation on subsidized firms is utilized. Only firms with subsidies from Vinnova included. All explanatory variables except firm age lagged one year. Cluster robust s.e. at firm level. Year, regional, and industry-fixed effects

\begin{tabular}{lll}
\hline & Full sample & Full sample \\
\hline Number of employees $(\log )$ & $0.87^{* * *}$ & $0.99^{* * *}$ \\
& $(0.049)$ & $(0.053)$ \\
Number of employees squared $(\log )$ & $-0.014^{*}$ & $-0.024^{* * *}$ \\
& $(0.0074)$ & $(0.0078)$ \\
Average wage cost $(\log )$ & $0.54^{* * *}$ & \\
Share of skilled workers & $(0.050)$ & \\
Equity ratio & $0.036^{* * *}$ & $0.038^{* * *}$ \\
& $(0.0011)$ & $(0.0011)$ \\
Firm age & 0.0037 & 0.0032 \\
& $(0.0044)$ & $(0.0037)$ \\
Labor productivity $(\log )$ & -0.0031 & 0.0040 \\
& $(0.0034)$ & $(0.0034)$ \\
Constant & & -0.035 \\
& & $(0.033)$ \\
Observations & $-10.5 * * *$ & $-7.62^{* * *}$ \\
& $(0.33)$ & $(0.27)$ \\
& & \\
& $1,721,525$ & $1,690,725$ \\
\hline
\end{tabular}


Table 11 Results from logit regressions

\begin{tabular}{|c|c|c|c|c|}
\hline & Single & Multiple & Single & Multiple \\
\hline Number of employees (log) & $\begin{array}{l}0.90 * * * \\
(0.063)\end{array}$ & $\begin{array}{l}0.86^{* * * *} \\
(0.074)\end{array}$ & $\begin{array}{l}1.04 * * * \\
(0.068)\end{array}$ & $\begin{array}{l}0.97 * * * \\
(0.080)\end{array}$ \\
\hline Number of employees squared (log) & $\begin{array}{l}-0.034 * * * \\
(0.0094)\end{array}$ & $\begin{array}{l}0.0089 \\
(0.011)\end{array}$ & $\begin{array}{l}-0.046^{* * *} \\
(0.0100)\end{array}$ & $\begin{array}{l}0.0012 \\
(0.012)\end{array}$ \\
\hline Average wage cost (log) & $\begin{array}{l}0.52 * * * \\
(0.063)\end{array}$ & $\begin{array}{l}0.56 * * * \\
(0.077)\end{array}$ & & \\
\hline Share of skilled workers & $\begin{array}{l}0.031 * * * \\
(0.0013)\end{array}$ & $\begin{array}{l}0.046 * * * \\
(0.0020)\end{array}$ & $\begin{array}{l}0.033 * * * \\
(0.0013)\end{array}$ & $\begin{array}{l}0.048 * * * \\
(0.0020)\end{array}$ \\
\hline Equity ratio & $\begin{array}{l}0.00020 \\
(0.0017)\end{array}$ & $\begin{array}{l}0.0067 * * \\
(0.0028)\end{array}$ & $\begin{array}{l}-0.000051 \\
(0.00052)\end{array}$ & $\begin{array}{l}0.0072 * * * \\
(0.0022)\end{array}$ \\
\hline Firm age & $\begin{array}{l}0.0047 \\
(0.0040)\end{array}$ & $\begin{array}{l}-0.012 * * \\
(0.0057)\end{array}$ & $\begin{array}{l}0.010 * * \\
(0.0041)\end{array}$ & $\begin{array}{l}-0.0036 \\
(0.0058)\end{array}$ \\
\hline Labor productivity (log) & & & $\begin{array}{l}-0.013 \\
(0.043)\end{array}$ & $\begin{array}{l}-0.061 \\
(0.049)\end{array}$ \\
\hline Constant & $\begin{array}{l}-10.4 * * * \\
(0.41)\end{array}$ & $\begin{array}{l}-12.7^{* * *} \\
(0.53)\end{array}$ & $\begin{array}{l}-7.77 * * * \\
(0.34)\end{array}$ & $\begin{array}{l}-9.55^{* * * *} \\
(0.43)\end{array}$ \\
\hline Observations & $1,717,945$ & $1,716,296$ & $1,687,628$ & $1,685,928$ \\
\hline
\end{tabular}

Standard errors in parentheses with significance levels given by $* p<0.1$, ** $p<0.05$, and $* * * p<0.01$. Dependent variable: dummy variable for subsidized and non-subsidized firms. Only the first observation on subsidized firms is utilized. Only firms with subsidies from Vinnova included. All explanatory variables except firm age lagged one year. Cluster robust s.e. at firm level. Year, regional, and industry-fixed effects

Table 12 Ordered logit

Standard errors in parentheses with significance levels given by $* p<0.1, * * p<0.05$, and $* * * p<0.01$. Dependent variable: dummy variable indicating whether a firm receives zero, a single, or multiple supports. Only the first observation on subsidized firms is utilized. Only firms with subsidies from Vinnova included. All explanatory variables except firm age lagged one year. Cluster robust s.e. at firm level. Year, regional, and industry-fixed effects

\begin{tabular}{lll}
\hline & Full sample & Full sample \\
\hline Number of employees $(\log )$ & $0.85^{* * *}$ & $0.97 * * *$ \\
& $(0.050)$ & $(0.054)$ \\
Number of employees squared $(\log )$ & -0.010 & $-0.020 * *$ \\
Average wage cost $(\log )$ & $(0.0076)$ & $(0.0081)$ \\
Share of skilled workers & $0.55^{* * *}$ & \\
& $(0.051)$ & \\
Equity ratio & $0.036 * * *$ & $0.038 * * *$ \\
Firm age & $(0.0011)$ & $(0.0011)$ \\
& 0.0039 & 0.0034 \\
Labor productivity $(\log )$ & $(0.0041)$ & $(0.0035)$ \\
& -0.0037 & 0.0034 \\
Observations & $(0.0034)$ & $(0.0035)$ \\
\hline & & -0.035 \\
& & $(0.033)$ \\
& & $2,037,123$ \\
\hline
\end{tabular}


Table 13 Results from NB regressions

\begin{tabular}{lll}
\hline & Full sample & Full sample \\
\hline Number of employees $(\log )$ & $1.00 * * *$ & $1.13 * * *$ \\
Number of employees squared $(\log )$ & $(0.025)$ & $(0.026)$ \\
& $-0.037 * * *$ & $-0.048^{* * *}$ \\
Average wage cost $(\log )$ & $(0.0033)$ & $(0.0034)$ \\
Share of skilled workers & $0.50 * * *$ & $0.039 * * *$ \\
Equity ratio & $(0.044)$ & $(0.00061)$ \\
Firm age & $0.037 * * *$ & 0.0044 \\
Labor productivity $(\log )$ & $(0.00061)$ & $(0.0029)$ \\
Constant & $0.0064 *$ & $-0.0048^{* * *}$ \\
Observations & $(0.0039)$ & $(0.0018)$ \\
\hline
\end{tabular}

Standard errors in parentheses with significance levels given by $* p<0.1$, **p $p<0.05$, and $* * * p<0.01$. Dependent variable: number of cumulative supports a firm receives. Robust standard errors. All explanatory variables except firm age lagged one year. Year, regional, and industry-fixed effects. Only firms with subsidies from Vinnova included

\section{C.2 Only main application from Vinnova regressions}

Table 14 Results from logit regressions

\begin{tabular}{lll}
\hline & Full sample & Full sample \\
\hline Number of employees $(\log )$ & $0.63^{* * *}$ & $0.62^{* * *}$ \\
& $(0.027)$ & $(0.028)$ \\
Number of employees squared $(\log )$ & $-0.046^{* * *}$ & $-0.045^{* * *}$ \\
Average wage cost $(\log )$ & $(0.0055)$ & $(0.0056)$ \\
& $-0.033^{*}$ & $0.0082^{* * *}$ \\
Share of skilled workers & $(0.017)$ & $(0.00039)$ \\
& $0.0086^{* * *}$ & $-0.00044 *$ \\
Equity ratio & $(0.00038)$ & $(0.00024)$ \\
Firm age & -0.00033 & $-0.012^{* * *}$ \\
Labor productivity $(\log )$ & $(0.00023)$ & $(0.0015)$
\end{tabular}


Table 14 (continued)

\begin{tabular}{llc}
\hline & Full sample & Full sample \\
\hline Constant & $-5.04 * * *$ & $-4.80^{* * * *}$ \\
& $(0.11)$ & $(0.10)$ \\
Observations & 2150170 & 2114670 \\
\hline
\end{tabular}

Standard errors in parentheses with significance levels given by $* p<0.1$, ** $p<0.05$, and $* * * p<0.01$. Dependent variable: dummy variable for subsidized and non-subsidized firms. Only the first observation on subsidized firms is utilized. Only Vinnova Coordinator/Subsidy recipient included. All explanatory variables except firm age lagged one year. Cluster robust s.e. at firm level. Year, regional, and industry-fixed effects

Table 15 Results from logit regressions

\begin{tabular}{|c|c|c|c|c|}
\hline & Single & Multiple & Single & Multiple \\
\hline Number of employees (log) & $\begin{array}{l}0.55^{* * *} \\
(0.031)\end{array}$ & $\begin{array}{l}1.09 * * * \\
(0.054)\end{array}$ & $\begin{array}{l}0.54 * * * \\
(0.031)\end{array}$ & $\begin{array}{l}1.12 * * * \\
(0.056)\end{array}$ \\
\hline Number of employees squared (log) & $\begin{array}{l}-0.056^{* * *} \\
(0.0066)\end{array}$ & $\begin{array}{l}-0.085^{* * *} \\
(0.0100)\end{array}$ & $\begin{array}{l}-0.055^{* * *} \\
(0.0067)\end{array}$ & $\begin{array}{l}-0.087 * * * \\
(0.010)\end{array}$ \\
\hline Average wage cost (log) & $\begin{array}{l}-0.067 * * * \\
(0.019)\end{array}$ & $\begin{array}{l}0.0053 \\
(0.032)\end{array}$ & & \\
\hline Share of skilled workers & $\begin{array}{l}0.0055^{* * * *} \\
(0.00044)\end{array}$ & $\begin{array}{l}0.016^{* * * *} \\
(0.00070)\end{array}$ & $\begin{array}{l}0.0053 * * * \\
(0.00045)\end{array}$ & $\begin{array}{l}0.015^{* * *} \\
(0.00074)\end{array}$ \\
\hline Equity ratio & $\begin{array}{l}-0.00040^{*} \\
(0.00024)\end{array}$ & $\begin{array}{l}-0.00023 \\
(0.00027)\end{array}$ & $\begin{array}{l}-0.00048^{*} \\
(0.00025)\end{array}$ & $\begin{array}{l}-0.00040 \\
(0.00027)\end{array}$ \\
\hline Firm age & $\begin{array}{l}-0.0083 * * * \\
(0.0018)\end{array}$ & $\begin{array}{l}-0.022 * * * \\
(0.0026)\end{array}$ & $\begin{array}{l}-0.0072 * * * \\
(0.0018)\end{array}$ & $\begin{array}{l}-0.018 * * * \\
(0.0026)\end{array}$ \\
\hline Labor productivity (log) & & & $\begin{array}{l}-0.070^{* * * *} \\
(0.016)\end{array}$ & $\begin{array}{l}-0.13^{* * *} \\
(0.025)\end{array}$ \\
\hline Constant & $\begin{array}{l}-5.08 * * * \\
(0.12)\end{array}$ & $\begin{array}{l}-7.08^{* * * *} \\
(0.19)\end{array}$ & $\begin{array}{l}-5.06^{* * * *} \\
(0.12)\end{array}$ & $\begin{array}{l}-6.39 * * * \\
(0.17)\end{array}$ \\
\hline Observations & $2,122,157$ & $2,091,387$ & $2,087,764$ & $2,057,113$ \\
\hline
\end{tabular}

Standard errors in parentheses with significance levels given by $* p<0.1, * * p<0.05$, and $* * * p<0.01$. Dependent variable: dummy variable for subsidized and non-subsidized firms. Only the first observation on subsidized firms is utilized. Only Vinnova Coordinator/Subsidy recipient included. All explanatory variables except firm age lagged one year. Cluster robust s.e. at firm level. Year, regional, and industry-fixed effects 
Table 16 Ordered logit

Standard errors in parentheses with significance levels given by $* p<0.1, * * p<0.05$, and $* * * p<0.01$. Dependent variable: dummy variable indicating whether a firm receives zero, a single, or multiple supports. Only the first observation on subsidized firms is utilized. Only Vinnova Coordinator/Subsidy recipient included. All explanatory variables except firm age lagged one year. Cluster robust s.e. at firm level. Year, regional, and industry-fixed effects. 100 iterations

Table 17 Results from NB regressions

Standard errors in parentheses with significance levels given by ${ }^{*} p<0.1, * * p<0.05$, and $* * * p<0.01$. Dependent variable: number of cumulative supports a firm receives. Robust standard errors. All explanatory variables except firm age lagged one year. Year, regional, and industry-fixed effects. Only Vinnova Coordinator/Subsidy recipient included

\begin{tabular}{lll}
\hline & Full sample & Full sample \\
\hline Number of employees $(\log )$ & $0.64 * * *$ & $0.64 * * *$ \\
& $(0.029)$ & $(0.029)$ \\
Number of employees squared $(\log )$ & $-0.044 * * *$ & $-0.043^{* * *}$ \\
& $(0.0059)$ & $(0.0060)$ \\
Average wage cost $(\log )$ & $-0.034 * *$ & \\
Share of skilled workers & $(0.017)$ & \\
Equity ratio & $0.0089 * * *$ & $0.0085^{* * *}$ \\
Firm age & $(0.00038)$ & $(0.00040)$ \\
& -0.00035 & $-0.00046^{*}$ \\
Labor productivity $(\log )$ & $(0.00023)$ & $(0.00024)$ \\
& $-0.013 * * *$ & $-0.011^{* * *}$ \\
Observations & $(0.0015)$ & $(0.0015)$ \\
\hline & & $-0.082^{* * *}$ \\
& & $(0.014)$ \\
& & $2,114,670$ \\
\hline
\end{tabular}

Full sample

Full sample

\begin{tabular}{lll}
\hline Number of employees $(\log )$ & $0.58 * * *$ & $0.59 * * *$ \\
Number of employees squared $(\log )$ & $-0.037 * * *$ & $-0.036 * * *$ \\
& $(0.0023)$ & $(0.0024)$ \\
Average wage cost $(\log )$ & 0.013 & \\
Share of skilled workers & $(0.0096)$ & \\
& $0.0099 * * *$ & $0.0094 * * *$ \\
Equity ratio & $(0.00015)$ & $(0.00016)$ \\
& -0.00026 & $-0.00038^{*}$ \\
Firm age & $(0.00021)$ & $(0.00023)$ \\
& $-0.014 * * *$ & $-0.011 * * *$ \\
Labor productivity $(\log )$ & $(0.00058)$ & $(0.00059)$ \\
& & $-0.086 * * *$ \\
Constant & & $(0.0073)$ \\
& $-5.32 * * *$ & $-4.80 * * *$ \\
Observations & $(0.056)$ & $(0.051)$ \\
& & $2,149,450$
\end{tabular}




\section{C.3 Only SAERG regressions}

Table 18 Results from logit regressions

Standard errors in parentheses with significance levels given by ${ }^{*} p<0.1,{ }^{*} p<0.05$, and $* * * p<0.01$. Dependent variable: dummy variable for subsidized and non-subsidized firms. Only the first observation on subsidized firms is utilized. Only firms with subsidies from SAERG included. All explanatory variables except firm age lagged one year. Cluster robust s.e. at firm level. Year, regional, and industry-fixed effects

\begin{tabular}{lll}
\hline & Full sample & Full sample \\
\hline Number of employees $(\log )$ & $0.71 * * *$ & $0.70^{* * *}$ \\
& $(0.030)$ & $(0.031)$ \\
Number of employees squared $(\log )$ & $-0.079^{* * *}$ & $-0.078^{* * *}$ \\
& $(0.0065)$ & $(0.0065)$ \\
Average wage cost $(\log )$ & $-0.13^{* * *}$ & \\
Share of skilled workers & $(0.018)$ & \\
Equity ratio & $0.0037 * * *$ & $0.0035^{* * *}$ \\
Firm age & $(0.00044)$ & $(0.00046)$ \\
& $-0.00055^{* *}$ & $-0.00063^{* *}$ \\
Labor productivity $(\log )$ & $(0.00023)$ & $(0.00024)$ \\
& $-0.011^{* * * *}$ & $-0.011^{* * *}$ \\
Constant & $(0.0017)$ & $(0.0017)$ \\
& & $-0.065^{* * *}$ \\
Observations & & $(0.016)$ \\
\hline
\end{tabular}

Table 19 Results from logit regressions

\begin{tabular}{|c|c|c|c|c|}
\hline & Single & Multiple & Single & Multiple \\
\hline Number of employees (log) & $\begin{array}{l}0.55^{* * *} \\
(0.033)\end{array}$ & $\begin{array}{l}1.46^{* * *} \\
(0.069)\end{array}$ & $\begin{array}{l}0.54 * * * \\
(0.034)\end{array}$ & $\begin{array}{l}1.46^{* * *} \\
(0.069)\end{array}$ \\
\hline Number of employees squared (log) & $\begin{array}{l}-0.064 * * * \\
(0.0074)\end{array}$ & $\begin{array}{l}-0.17 * * * \\
(0.013)\end{array}$ & $\begin{array}{l}-0.063 * * * \\
(0.0075)\end{array}$ & $\begin{array}{l}-0.17 * * * \\
(0.013)\end{array}$ \\
\hline Average wage cost $(\log )$ & $\begin{array}{l}-0.12^{* * *} \\
(0.019)\end{array}$ & $\begin{array}{l}-0.19 * * * \\
(0.037)\end{array}$ & & \\
\hline Share of skilled workers & $\begin{array}{l}0.0030 * * * \\
(0.00048)\end{array}$ & $\begin{array}{l}0.0057 * * * \\
(0.00100)\end{array}$ & $\begin{array}{l}0.0029 * * * \\
(0.00049)\end{array}$ & $\begin{array}{l}0.0053^{* * *} \\
(0.0010)\end{array}$ \\
\hline Equity ratio & $\begin{array}{l}-0.00049^{*} \\
(0.00026)\end{array}$ & $\begin{array}{l}-0.00080^{* * * *} \\
(0.00022)\end{array}$ & $\begin{array}{l}-0.00056^{* *} \\
(0.00027)\end{array}$ & $\begin{array}{l}-0.00089^{* * * *} \\
(0.00023)\end{array}$ \\
\hline Firm age & $\begin{array}{l}-0.0081^{* * *} \\
(0.0018)\end{array}$ & $\begin{array}{l}-0.018^{* * *} \\
(0.0031)\end{array}$ & $\begin{array}{l}-0.0076^{* * * *} \\
(0.0019)\end{array}$ & $\begin{array}{l}-0.017 * * * \\
(0.0031)\end{array}$ \\
\hline Labor productivity (log) & & & $\begin{array}{l}-0.070 * * * \\
(0.017)\end{array}$ & $\begin{array}{l}-0.077^{* *} \\
(0.032)\end{array}$ \\
\hline Constant & $\begin{array}{l}-5.12^{* * *} \\
(0.13)\end{array}$ & $\begin{array}{l}-7.13^{* * *} \\
(0.26)\end{array}$ & $\begin{array}{l}-5.34 * * * \\
(0.14)\end{array}$ & $\begin{array}{l}-7.68 * * * \\
(0.26)\end{array}$ \\
\hline
\end{tabular}


Table 19 (continued)

\begin{tabular}{|c|c|c|c|c|}
\hline & Single & Multiple & Single & Multiple \\
\hline Observations & $2,118,126$ & $2,083,361$ & $2,084,115$ & $2,049,882$ \\
\hline
\end{tabular}

Standard errors in parentheses with significance levels given by $* p<0.1$, **p $p<0.05$, and $* * * p<0.01$. Dependent variable: dummy variable for subsidized and non-subsidized firms. Only the first observation on subsidized firms is utilized. Only firms with subsidies from SAERG included. All explanatory variables except firm age lagged one year. Cluster robust s.e. at firm level. Year, regional, and industry-fixed effects

Table 20 Ordered logit

Standard errors in parentheses with significance levels given by $* p<0.1, * * p<0.05$, and $* * * p<0.01$. Dependent variable: dummy variable indicating whether a firm receives zero, a single, or multiple supports. Only the first observation on subsidized firms is utilized. Only firms with subsidies from SAERG included. All explanatory variables except firm age lagged one year. Cluster robust s.e. at firm level. Year, regional, and industry-fixed effects

Table 21 Results from NB regressions

Standard errors in parentheses with significance levels given by ${ }^{*} p<0.1, * * p<0.05$, and $* * * p<0.01$. Dependent variable: number of cumulative supports a firm receives. Robust standard errors. All explanatory variables except firm age lagged one year. Year, regional, and industry-fixed effects. Only firms with subsidies from SAERG included

\begin{tabular}{lll}
\hline & Full sample & Full sample \\
\hline Number of employees $(\log )$ & $0.74 * * *$ & $0.73 * * *$ \\
& $(0.030)$ & $(0.031)$ \\
Number of employees squared $(\log )$ & $-0.081^{* * *}$ & $-0.080^{* * *}$ \\
& $(0.0065)$ & $(0.0065)$ \\
Average wage cost $(\log )$ & $-0.13^{* * *}$ & \\
Share of skilled workers & $(0.018)$ & \\
& $0.0038^{* * *}$ & $0.0036^{* * *}$ \\
Equity ratio & $(0.00045)$ & $(0.00046)$ \\
Firm age & $-0.00058^{* * *}$ & $-0.00065^{* * *}$ \\
& $(0.00023)$ & $(0.00024)$ \\
Labor productivity $(\log )$ & $-0.011^{* * *}$ & $-0.011^{* * *}$ \\
& $(0.0017)$ & $(0.0017)$ \\
& & $-0.066^{* * *}$ \\
Observations & & $(0.016)$ \\
\hline
\end{tabular}

\begin{tabular}{|c|c|c|}
\hline & Full sample & Full sample \\
\hline Number of employees (log) & $\begin{array}{l}0.68 * * * \\
(0.0099)\end{array}$ & $\begin{array}{l}0.67 * * * \\
(0.0099)\end{array}$ \\
\hline $\begin{array}{l}\text { Number of employees squared } \\
(\log )\end{array}$ & $\begin{array}{l}-0.074 * * * \\
(0.0020)\end{array}$ & $\begin{array}{l}-0.073^{* * *} \\
(0.0020)\end{array}$ \\
\hline Average wage cost $(\log )$ & $\begin{array}{l}-0.10 * * * \\
(0.0087)\end{array}$ & \\
\hline Share of skilled workers & $\begin{array}{l}0.0037 * * * \\
(0.00016)\end{array}$ & $\begin{array}{l}0.0034 * * * \\
(0.00016)\end{array}$ \\
\hline Equity ratio & $\begin{array}{l}-0.00057 * * * \\
(0.00020)\end{array}$ & $\begin{array}{l}-0.00063^{* * * *} \\
(0.00021)\end{array}$ \\
\hline Firm age & $\begin{array}{l}-0.011^{* * *} \\
(0.00051)\end{array}$ & $\begin{array}{l}-0.0098^{* * * *} \\
(0.00051)\end{array}$ \\
\hline Labor productivity (log) & & $\begin{array}{l}-0.049 * * * \\
(0.0069)\end{array}$ \\
\hline Constant & $\begin{array}{l}-5.22 * * * \\
(0.054)\end{array}$ & $\begin{array}{l}-5.48 * * * \\
(0.051)\end{array}$ \\
\hline Observations & $2,159,564$ & $2,124,990$ \\
\hline
\end{tabular}




\section{C.4 Total factor productivity regressions}

Table 22 Results from logit regressions

Standard errors in parentheses with significance levels given by $* p<0.1, * * p<0.05$, and $* * * p<0.01$. Dependent variable: dummy variable for subsidized and non-subsidized firms. Only the first observation on subsidized firms is utilized.

All explanatory variables except firm age lagged one year. Cluster robust s.e. at firm level. Year, regional, and industry-fixed effects

\begin{tabular}{lll}
\hline & Full sample & Full sample \\
\hline Number of employees $(\log )$ & $0.56^{* * *}$ & $0.56 * * *$ \\
& $(0.025)$ & $(0.025)$ \\
Number of employees squared $(\log )$ & $-0.032 * * *$ & $-0.032 * * *$ \\
& $(0.0050)$ & $(0.0050)$ \\
Wooldridge Prod, winsorized 95\% & $-0.41 * * *$ & \\
Share of skilled workers & $(0.019)$ & \\
Equity ratio & $0.0090 * * *$ & $0.0090 * * *$ \\
Firm age & $(0.00038)$ & $(0.00038)$ \\
LevPet Prod, winsorized 95\% & $-0.00055^{* *}$ & $-0.00054 * *$ \\
& $(0.00024)$ & $(0.00024)$ \\
Constant & $-0.011^{*} * *$ & $-0.011 * * *$ \\
& $(0.0015)$ & $(0.0015)$ \\
Observations & & $-0.40 * * *$ \\
\hline
\end{tabular}

Table 23 Results from logit regressions

\begin{tabular}{|c|c|c|c|c|}
\hline & Single & Multiple & Single & Multiple \\
\hline Number of employees (log) & $\begin{array}{l}0.49 * * * \\
(0.030)\end{array}$ & $\begin{array}{l}1.01 * * * \\
(0.049)\end{array}$ & $\begin{array}{l}0.49 * * * \\
(0.030)\end{array}$ & $\begin{array}{l}1.01 * * * \\
(0.049)\end{array}$ \\
\hline Number of employees squared (log) & $\begin{array}{l}-0.045^{* * *} \\
(0.0062)\end{array}$ & $\begin{array}{l}-0.070^{* * *} \\
(0.0087)\end{array}$ & $\begin{array}{l}-0.044 * * * \\
(0.0061)\end{array}$ & $\begin{array}{l}-0.069 * * * \\
(0.0086)\end{array}$ \\
\hline Wooldridge Prod, winsorized $90 \%$ & $\begin{array}{l}-0.36^{* * * *} \\
(0.022)\end{array}$ & $\begin{array}{l}-0.52 * * * \\
(0.033)\end{array}$ & & \\
\hline Share of skilled workers & $\begin{array}{l}0.0059 * * * \\
(0.00043)\end{array}$ & $\begin{array}{l}0.016 * * * \\
(0.00070)\end{array}$ & $\begin{array}{l}0.0059 * * * \\
(0.00043)\end{array}$ & $\begin{array}{l}0.016^{* * * *} \\
(0.00070)\end{array}$ \\
\hline Equity ratio & $\begin{array}{l}-0.00059 * * \\
(0.00023)\end{array}$ & $\begin{array}{l}-0.00046^{* *} \\
(0.00023)\end{array}$ & $\begin{array}{l}-0.00059 * * \\
(0.00023)\end{array}$ & $\begin{array}{l}-0.00045^{*} \\
(0.00023)\end{array}$ \\
\hline Firm age & $\begin{array}{l}-0.0063 * * * \\
(0.0017)\end{array}$ & $\begin{array}{l}-0.017 * * * \\
(0.0025)\end{array}$ & $\begin{array}{l}-0.0063 * * * \\
(0.0017)\end{array}$ & $\begin{array}{l}-0.017 * * * \\
(0.0025)\end{array}$ \\
\hline LevPet Prod, winsorized $95 \%$ & & & $\begin{array}{l}-0.35^{* * *} \\
(0.022)\end{array}$ & $\begin{array}{l}-0.51 * * * \\
(0.033)\end{array}$ \\
\hline Constant & $\begin{array}{l}-4.19 * * * \\
(0.10)\end{array}$ & $\begin{array}{l}-5.34 * * * \\
(0.14)\end{array}$ & $\begin{array}{l}-4.18^{* * * *} \\
(0.11)\end{array}$ & $\begin{array}{l}-5.32^{* * *} \\
(0.15)\end{array}$ \\
\hline Observations & $2,088,835$ & $2,058,389$ & $2,088,835$ & $2,058,389$ \\
\hline
\end{tabular}

Standard errors in parentheses with significance levels given by $* p<0.1$, ** $p<0.05$, and $* * * p<0.01$. Dependent variable: dummy variable for subsidized and non-subsidized firms. Only the first observation on subsidized firms is utilized. All explanatory variables except firm age lagged one year. Cluster robust s.e. at firm level. Year, regional, and industry-fixed effects 
Table 24 Ordered logit

Standard errors in parentheses with significance levels given by ${ }^{*} p<0.1, * * p<0.05$, and $* * * p<0.01$. Dependent variable: dummy variable indicating whether a firm receives zero, a single, or multiple supports. Only the first observation on subsidized firms is utilized. 100 iteration. All explanatory variables except firm age lagged one year. Cluster robust s.e. at firm level. Year, regional, and industry-fixed effects

Table 25 Results from NB regressions

Standard errors in parentheses with significance levels given by ${ }^{*} p<0.1, * * p<0.05$, and $* * * p<0.01$. Dependent variable: number of cumulative supports a firm receives. All explanatory variables except firm age lagged one year. Robust standard errors. Year, regional, and industry-fixed effects

\begin{tabular}{lll}
\hline & Full sample & Full sample \\
\hline Number of employees $(\log )$ & $0.56^{* * *}$ & $0.57 * * *$ \\
& $(0.027)$ & $(0.027)$ \\
Number of employees squared $(\log )$ & $-0.029 * * *$ & $-0.029 * * *$ \\
& $(0.0054)$ & $(0.0054)$ \\
Wooldridge Prod, winsorized 95\% & $-0.42^{* * *}$ & \\
Share of skilled workers & $(0.019)$ & \\
Equity ratio & $0.0093 * * *$ & $0.0093 * * *$ \\
Firm age & $(0.00038)$ & $(0.00038)$ \\
& $-0.00056^{* * *}$ & $-0.00055^{* *}$ \\
LevPet Prod, winsorized 95\% & $(0.00024)$ & $(0.00024)$ \\
& $-0.011^{* * *}$ & $-0.010^{* * *}$ \\
& $(0.0015)$ & $(0.0015)$ \\
Observations & & $-0.41 * * *$ \\
\hline
\end{tabular}

\begin{tabular}{lll}
\hline & Full sample & Full sample \\
\hline Number of employees $(\log )$ & $0.53 * * *$ & $0.53 * * *$ \\
& $(0.0090)$ & $(0.0089)$ \\
Number of employees squared (log) & $-0.024 * * *$ & $-0.024 * * *$ \\
& $(0.0017)$ & $(0.0017)$ \\
Wooldridge Prod, winsorized 95\% & $-0.40 * * *$ & \\
Share of skilled workers & $(0.0095)$ & \\
Equity ratio & $0.011 * * *$ & $0.011 * * *$ \\
Firm age & $(0.00015)$ & $(0.00015)$ \\
& $-0.00047 *$ & $-0.00046 *$ \\
LevPet Prod, winsorized 95\% & $(0.00026)$ & $(0.00026)$ \\
& $-0.010 * * *$ & $-0.010^{* * *}$ \\
Constant & $(0.00059)$ & $(0.00059)$ \\
& & $-0.39 * * *$ \\
& & $(0.0096)$ \\
& $-3.94 * * *$ & $-3.93 * * *$ \\
& $(0.042)$ & $(0.043)$ \\
& & $2,152,222$ \\
\hline
\end{tabular}




\section{C.5 Less than 25 supports regressions}

Table 26 Results from logit regressions

Standard errors in parentheses with significance levels given by $* p<0.1, * * p<0.05$, and $* * * p<0.01$. Dependent variable: dummy variable for subsidized and non-subsidized firms. Only the first observation on subsidized firms is utilized. Only firms with less than 25 subsidies included. All explanatory variables except firm age lagged one year. Cluster robust s.e. at firm level. Year, regional, and industry-fixed effects

\begin{tabular}{|c|c|c|}
\hline & Full sample & Full sample \\
\hline Number of employees (log) & $\begin{array}{l}0.58 * * * \\
(0.025)\end{array}$ & $\begin{array}{l}0.58 * * * \\
(0.025)\end{array}$ \\
\hline Number of employees squared (log) & $\begin{array}{l}-0.029 * * * \\
(0.0048)\end{array}$ & $\begin{array}{l}-0.028 * * * \\
(0.0049)\end{array}$ \\
\hline Average wage cost (log) & $\begin{array}{l}0.0027 \\
(0.017)\end{array}$ & \\
\hline Share of skilled workers & $\begin{array}{l}0.0093 * * * \\
(0.00037)\end{array}$ & $\begin{array}{l}0.0089 * * * \\
(0.00038)\end{array}$ \\
\hline Equity ratio & $\begin{array}{l}-0.00031 \\
(0.00023)\end{array}$ & $\begin{array}{l}-0.00043^{*} \\
(0.00024)\end{array}$ \\
\hline Firm age & $\begin{array}{l}-0.013 \text { *** } \\
(0.0015)\end{array}$ & $\begin{array}{l}-0.011 * * * \\
(0.0015)\end{array}$ \\
\hline Labor productivity (log) & & $\begin{array}{l}-0.067 * * * \\
(0.014)\end{array}$ \\
\hline Constant & $\begin{array}{l}-5.16^{* * *} \\
(0.11)\end{array}$ & $\begin{array}{l}-4.81 * * * \\
(0.100)\end{array}$ \\
\hline Observations & $2,153,514$ & $2,117,798$ \\
\hline
\end{tabular}

Table 27 Results from logit regressions

\begin{tabular}{lllll}
\hline & Single & Multiple & Single & Multiple \\
\hline Number of employees $(\log )$ & $0.50^{* * *}$ & $1.01 * * *$ & $0.50^{* * *}$ & $1.04 * * *$ \\
Number of employees squared $(\log )$ & $(0.029)$ & $(0.047)$ & $(0.029)$ & $(0.049)$ \\
& $(0.0060)$ & $(0.0083)$ & $(0.0061)$ & $(0.0086)$ \\
Average wage cost $(\log )$ & $-0.039 * *$ & $0.055^{*}$ & & $-0.065^{* * *}$ \\
Share of skilled workers & $(0.019)$ & $(0.033)$ & & $0.016^{* * *}$ \\
Equity ratio & $0.0061^{* * *}$ & $0.017 * * *$ & $0.0059 * * *$ & $(0.00072)$ \\
Firm age & $(0.00042)$ & $(0.00069)$ & $(0.00044)$ & -0.00039 \\
Labor productivity $(\log )$ & -0.00038 & -0.00022 & $-0.00047 *$ & $(0.00025)$ \\
Constant & $(0.00024)$ & $(0.00026)$ & $(0.00025)$ & $-0.018^{* * *}$ \\
& $-0.0079 * * *$ & $-0.021 * * *$ & $-0.0067 * * *$ & $(0.0025)$ \\
Observations & $(0.0017)$ & $(0.0025)$ & $(0.0017)$ & $-0.12 * * *$ \\
\hline
\end{tabular}

Standard errors in parentheses with significance levels given by $* p<0.1$, ** $p<0.05$, and $* * * p<0.01$. Dependent variable: dummy variable for subsidized and non-subsidized firms. Only the first observation on subsidized firms is utilized. Only firms with less than 25 subsidies included. All explanatory variables except firm age lagged one year. Cluster robust s.e. at firm level. Year, regional, and industry-fixed effects 
Table 28 Ordered logit

Standard errors in parentheses with significance levels given by $* p<0.1, * * p<0.05$, and $* * * p<0.01$. Dependent variable: dummy variable indicating whether a firm receives zero, a single, or multiple supports. Only the first observation on subsidized firms is utilized. Only firms with less than 25 subsidies included. 100 iterations. All explanatory variables except firm age lagged one year. Cluster robust s.e. at firm level. Year, regional, and industry-fixed effects

Table 29 Results from NB regressions

Standard errors in parentheses with significance levels given by $* p<0.1, * * p<0.05$, and $* * * p<0.01$. Dependent variable: number of cumulative supports a firm receives. Robust standard errors. Year, regional, and industry-fixed effects. All explanatory variables except firm age lagged one year. Only firms with less than 25 subsidies included

\begin{tabular}{lll}
\hline & Full sample & Full sample \\
\hline Number of employees $(\log )$ & $0.58 * * *$ & $0.59 * * *$ \\
& $(0.026)$ & $(0.027)$ \\
Number of employees squared $(\log )$ & $-0.026 * * *$ & $-0.025 * * *$ \\
Average wage cost $(\log )$ & $(0.0052)$ & $(0.0053)$ \\
& 0.0027 & \\
Share of skilled workers & $(0.018)$ & \\
Equity ratio & $0.0097 * * *$ & $0.0092 * * *$ \\
Firm age & $(0.00037)$ & $(0.00039)$ \\
& -0.00033 & $-0.00044 *$ \\
Labor productivity $(\log )$ & $(0.00023)$ & $(0.00024)$ \\
& $-0.013 * * *$ & $-0.011^{* * *}$ \\
Observations & $(0.0015)$ & $(0.0015)$ \\
\hline & & $-0.069 * * *$ \\
& & $(0.014)$ \\
& & $2,117,798$ \\
\hline
\end{tabular}

\begin{tabular}{|c|c|c|}
\hline & Full sample & Full sample \\
\hline Number of employees (log) & $\begin{array}{l}0.55 * * * \\
(0.0089)\end{array}$ & $\begin{array}{l}0.56 * * * \\
(0.0091)\end{array}$ \\
\hline Number of employees squared (log) & $\begin{array}{l}-0.024 * * * \\
(0.0016)\end{array}$ & $\begin{array}{l}-0.024 * * * \\
(0.0017)\end{array}$ \\
\hline Average wage cost (log) & $\begin{array}{l}0.059 * * * \\
(0.0100)\end{array}$ & \\
\hline Share of skilled workers & $\begin{array}{l}0.011 * * * \\
(0.00015)\end{array}$ & $\begin{array}{l}0.010 * * * \\
(0.00015)\end{array}$ \\
\hline Equity ratio & $\begin{array}{l}-0.00021 \\
(0.00021)\end{array}$ & $\begin{array}{l}-0.00034 \\
(0.00023)\end{array}$ \\
\hline Firm age & $\begin{array}{l}-0.015^{* * *} \\
(0.00053)\end{array}$ & $\begin{array}{l}-0.012^{* * *} \\
(0.00053)\end{array}$ \\
\hline Labor productivity (log) & & $\begin{array}{l}-0.067 * * * \\
(0.0074)\end{array}$ \\
\hline Constant & $\begin{array}{l}-5.52^{* * *} \\
(0.057)\end{array}$ & $\begin{array}{l}-4.88^{* * *} \\
(0.051)\end{array}$ \\
\hline Observations & $2,189,540$ & $2,152,554$ \\
\hline
\end{tabular}




\section{C.6 SMEs regressions}

Table 30 Results from logit regressions.

Standard errors in parentheses with significance levels given by $* p<0.1, * * p<0.05$, and $* * * p<0.01$. Dependent variable: dummy variable for subsidized and non-subsidized firms. Only the first observation on subsidized firms is utilized. Only firms with less than 250 employees included. Cluster robust s.e. at firm level. All explanatory variables except firm age lagged one year. Year, regional, and industry-fixed effects

\begin{tabular}{lll}
\hline & Full sample & Full sample \\
\hline Number of employees $(\log )$ & $0.57 * * *$ & $0.56^{* * *}$ \\
& $(0.034)$ & $(0.035)$ \\
Number of employees squared $(\log )$ & -0.014 & -0.010 \\
& $(0.0093)$ & $(0.0095)$ \\
Average wage cost $(\log )$ & -0.019 & \\
Share of skilled workers & $(0.018)$ & \\
& $0.0093^{* * *}$ & $0.0089^{* * *}$ \\
Equity ratio & $(0.00038)$ & $(0.00039)$ \\
Firm age & -0.00032 & $-0.00044^{*}$ \\
& $(0.00023)$ & $(0.00024)$ \\
Labor productivity $(\log )$ & $-0.015^{* * * *}$ & $-0.013^{* * *}$ \\
& $(0.0016)$ & $(0.0016)$ \\
Constant & & $-0.065^{* * *}$ \\
& & $(0.015)$ \\
Observations & $-5.17^{* * * *}$ & $-4.95^{* * *}$ \\
\hline
\end{tabular}

Table 31 Results from logit regressions

\begin{tabular}{|c|c|c|c|c|}
\hline & Single & Multiple & Single & Multiple \\
\hline Number of employees $(\log )$ & $\begin{array}{l}0.46^{* * * *} \\
(0.039)\end{array}$ & $\begin{array}{l}1.16^{* * * *} \\
(0.070)\end{array}$ & $\begin{array}{l}0.45 * * * \\
(0.040)\end{array}$ & $\begin{array}{l}1.18 * * * \\
(0.074)\end{array}$ \\
\hline Number of employees squared (log) & $\begin{array}{l}-0.021^{*} \\
(0.011)\end{array}$ & $\begin{array}{l}-0.074 * * * \\
(0.017)\end{array}$ & $\begin{array}{l}-0.019^{*} \\
(0.011)\end{array}$ & $\begin{array}{l}-0.075^{* * *} \\
(0.018)\end{array}$ \\
\hline Average wage cost (log) & $\begin{array}{l}-0.052 * * * \\
(0.020)\end{array}$ & $\begin{array}{l}0.015 \\
(0.034)\end{array}$ & & \\
\hline Share of skilled workers & $\begin{array}{l}0.0061 * * * \\
(0.00043)\end{array}$ & $\begin{array}{l}0.017 * * * \\
(0.00072)\end{array}$ & $\begin{array}{l}0.0059 * * * \\
(0.00044)\end{array}$ & $\begin{array}{l}0.017 * * * \\
(0.00076)\end{array}$ \\
\hline Equity ratio & $\begin{array}{l}-0.00039 \\
(0.00024)\end{array}$ & $\begin{array}{l}-0.00020 \\
(0.00029)\end{array}$ & $\begin{array}{l}-0.00048^{*} \\
(0.00025)\end{array}$ & $\begin{array}{l}-0.00038 \\
(0.00028)\end{array}$ \\
\hline Firm age & $\begin{array}{l}-0.0096 * * * \\
(0.0018)\end{array}$ & $\begin{array}{l}-0.025 * * * \\
(0.0027)\end{array}$ & $\begin{array}{l}-0.0085^{* * * *} \\
(0.0018)\end{array}$ & $\begin{array}{l}-0.021 * * * \\
(0.0027)\end{array}$ \\
\hline Labor productivity (log) & & & $\begin{array}{l}-0.054 * * * \\
(0.017)\end{array}$ & $\begin{array}{l}-0.12 * * * \\
(0.026)\end{array}$ \\
\hline Constant & $\begin{array}{l}-5.16^{* * *} \\
(0.12)\end{array}$ & $\begin{array}{l}-7.37 * * * \\
(0.20)\end{array}$ & $\begin{array}{l}-5.16^{* * * *} \\
(0.12)\end{array}$ & $\begin{array}{l}-6.74 * * * \\
(0.18)\end{array}$ \\
\hline Observations & $2,055,878$ & $2,024,693$ & $2,022,330$ & $1,991,266$ \\
\hline
\end{tabular}

Standard errors in parentheses with significance levels given by $* p<0.1$, ** $p<0.05$, and $* * * p<0.01$. Dependent variable: dummy variable for subsidized and non-subsidized firms. Only the first observation on subsidized firms is utilized. Only firms with less than 250 employees included. Cluster robust s.e. at firm level. All explanatory variables except firm age lagged one year. Year, regional, and industry-fixed effects 
Table 32 Ordered logit

Standard errors in parentheses with significance levels given by $* p<0.1, * * p<0.05$, and $* * * p<0.01$. Dependent variable: dummy variable indicating whether a firm receives zero, a single, or multiple supports. Only the first observation on subsidized firms is utilized. Only firms with less than 250 employees included. All explanatory variables except firm age lagged one year. Cluster robust s.e. at firm level. Year, regional, and industry-fixed effects

Table 33 Results from NB regressions

Standard errors in parentheses with significance levels given by $* p<0.1, * * p<0.05$, and $* * * p<0.01$. Dependent variable: number of cumulative supports a firm receives. Robust standard errors. Year, regional, and industry-fixed effects. All explanatory variables except firm age lagged one year. Only firms with less than 250 employees included

\begin{tabular}{lll}
\hline & Full sample & Full sample \\
\hline Number of employees (log) & $0.57 * * *$ & $0.55 * * *$ \\
& $(0.034)$ & $(0.035)$ \\
Number of employees squared (log) & -0.0048 & -0.00062 \\
Average wage cost $(\log )$ & $(0.0093)$ & $(0.0096)$ \\
& -0.021 & \\
Share of skilled workers & $(0.018)$ & \\
Equity ratio & $0.0097 * * *$ & $0.0092^{* * *}$ \\
Firm age & $(0.00038)$ & $(0.00040)$ \\
Labor productivity (log) & -0.00033 & $-0.00045^{*}$ \\
& $(0.00023)$ & $(0.00024)$ \\
& $-0.015 * * *$ & $-0.013 * * *$ \\
Observations & $(0.0016)$ & $(0.0016)$ \\
\hline & & $-0.069^{* * *}$ \\
& & $(0.015)$ \\
& $2,080,752$ & $2,046,078$ \\
\hline
\end{tabular}

\begin{tabular}{|c|c|c|}
\hline & Full sample & Full sample \\
\hline Number of employees (log) & $\begin{array}{l}0.62 * * * \\
(0.014)\end{array}$ & $\begin{array}{l}0.61 * * * \\
(0.014)\end{array}$ \\
\hline Number of employees squared (log) & $\begin{array}{l}-0.028^{* * * *} \\
(0.0037)\end{array}$ & $\begin{array}{l}-0.025^{* * * *} \\
(0.0037)\end{array}$ \\
\hline Average wage cost (log) & $\begin{array}{l}0.038 * * * \\
(0.010)\end{array}$ & \\
\hline Share of skilled workers & $\begin{array}{l}0.011 * * * \\
(0.00015)\end{array}$ & $\begin{array}{l}0.010 * * * \\
(0.00016)\end{array}$ \\
\hline Equity ratio & $\begin{array}{l}-0.00021 \\
(0.00021)\end{array}$ & $\begin{array}{l}-0.00034 \\
(0.00023)\end{array}$ \\
\hline Firm age & $\begin{array}{l}-0.017 * * * \\
(0.00053)\end{array}$ & $\begin{array}{l}-0.014 * * * \\
(0.00054)\end{array}$ \\
\hline Labor productivity (log) & & $\begin{array}{l}-0.064 * * * \\
(0.0079)\end{array}$ \\
\hline Constant & $\begin{array}{l}-5.56^{* * *} \\
(0.059)\end{array}$ & $\begin{array}{l}-5.06^{* * *} \\
(0.054)\end{array}$ \\
\hline Observations & $2,110,102$ & $2,074,333$ \\
\hline
\end{tabular}


Open Access This article is distributed under the terms of the Creative Commons Attribution 4.0 International License (http://creativecommons.org/licenses/by/4.0/), which permits unrestricted use, distribution, and reproduction in any medium, provided you give appropriate credit to the original author(s) and the source, provide a link to the Creative Commons license, and indicate if changes were made.

\section{References}

Aerts K, Czarnitzki D, Fier A (2006) Econometric evaluation of public r\&d policies: current state of the art. Technical report, K.U.Leuven and ZEW Centre for European Economic Research (ZEW)

Afcha S (2012) Analyzing the interaction between R\&D subsidies and firm's innovation strategy. J Technol Manag Innov 7(3):57-70

Akay A (2012) Finite-sample comparison of alternative methods for estimating dynamic panel data models. Journal of Applied Econometrics 27(7):1189-1204

Arqué-Castells P, Mohnen P (2015) Sunk costs, extensive R\&D subsidies and permanent inducement effects. $\mathrm{J}$ Ind Econ 63(3):458-494

Aschhoff B (2010) Who gets the money? Jahrbücher r Natl Stat 230(5):522-546

Baldwin RE, Robert-Nicoud F (2007) Entry and asymmetric lobbying: why governments pick losers. J Eur Econ Assoc 5(5):1064-1093

Baumol WJ (1990) Entrepreneurship: productive, unproductive, and destructive. Journal of Political Economy

Becker L (2015) Effectiveness of public innovation support in europe: does public support foster turnover, employment and labour productivity? Technical report, University of Goettingen, Department of Economics

Blanes JV, Isabel B (2004) Who participates in R\&D subsidy programs? The case of spanish manufacturing firms. Res Policy 33(10):1459-1476

Bronzini R, Iachini E (2010) Are incentives to R\&D effective? Evidence of heterogeneous effects from a regional program in italy. Technical report, Banca d'Italia, mimeo

Buigues P-A, Sekkat K (2011) Public subsidies to business: an international comparison, Journal of Industry. Compet Trade 11(1):1-24

Carreira C, Silva F (2010) No deep pockets: some stylized empirical results on firms' financial constraints. J Econ Surv 24(4):731-753

Catozzella A, Vivarelli M (2011) Beyond additionality: are innovation subsidies counterproductive?, Technical report. IZA Discussion Paper No. 5746

Cerulli G, Poti B (2008) Evaluating the effect of public subsidies on firm R\&D activity: an application to Italy using the community innovation survey. Technical report, Institute for Economic Research on Firms and Growth-Moncalieri (TO)

Che Y-K, Gale I (1997) Rent dissipation when rent seekers are budget constrained. Publ Choice 92(1-2):109_ 126

Cheng H, Hanbing F, Takeo H, Dezhuang H (2019) Do innovation subsidies make chinese firms more innovative? evidence from the china employer employee survey, Working Paper 25432, National Bureau of Economic Research

Criscuolo C, Ralf M, Henry O, Van Reenen J (2012) The causal effects of an industrial policy, Working Paper 17842, National Bureau of Economic Research

Czarnitzki D, Delanote J (2014) R\&d subsidies to small young companies: should the independent and hightech ones be favored in the granting process?. Technical report, Centre for European Economic Research (ZEW)

Dahlberg M, Johansson E (2002) On the vote-purchasing behavior of incumbent governments. Amer Polit Sci Rev 96(1):27-40

David PA, Hall BH, Toole AA (2000) Is public R\&D a complement or substitute for private R\&D? A review of the econometric evidence. Res Policy 29(4):497-529

Du J, Mickiewicz T (2016) Subsidies, rent seeking and performance: being young, small or private in China. J Bus Ventur 31(1):22-38

Feldman MP, Kelley MR (2001) Winning an award from the advanced technology program: pursuing r\&d strategies in the public interest and benefiting from a halo effect, Technical report, NISTIR 6577, US Department of Commerce

González X, Jaumandreu J, Consuelo P (2005) Barriers to innovation and subsidy effectiveness. RAND Journal of Economics 36(4):930-950

Goolsbee A (1998) Does government R\&D policy mainly benefit scientists and engineers? Amer Econ Rev 88(2):298-302 
Grossman GM, Helpman E (1994) Protection for sale. Amer Econ Rev 84(4):833-850

Grossmann M, Dietl H (2012) Asymmetric contests with liquidity constraints. Publ Choice 150(3-4):691-713

Guo D, Guo J, Jiang K (2014) Government subsidized R\&D and innovation outputs: an empirical analysis of china's innofund program, Technical Report 494, Stanford Center for International Development Working Paper Series

Gustafsson A, Stephan A, Hallman A, Karlsson N (2016) The "sugar rush" from innovation subsidies: a robust political economy perspective. Empirica 43(4):729-756

Hall BronwynH (2002) The financing of research and development. Oxford Rev Econ Policy 18(1):35-51

Heijs J (2005) Identification of firms supported by technology policies: the case of spanish low interest credits. Sci Publ Policy 32(3):219-230

Howell ST (2017) Financing innovation: evidence from r\&d grants. Amer Econ Rev 107(4):1136-64

Huergo E, Trenado M (2010) The application for and the awarding of low-interest credits to finance R\&D projects. Rev Ind Organ 37(3):237-259

Hussinger K (2008) RD and subsidies at the firm level: an application of parametric and semiparametric two-step selection models. J Appl Econ 23(6):729-747

Klein PG, Mahoney JT, McGahan AM, Pitelis CN (2010) Toward a theory of public entrepreneurship. Eur Manag Rev 7(1):1-15

Klette TJ, Møen J, Griliches Z (2000) Do subsidies to commercial R\&D, reduce market failures? Microeconometric evaluation studies. Res Policy 29(4):471-495

Klette TJ, Møen J (2012) R\&D investment responses to R\&D subsidies: a theoretical analysis and a microeconometric study. World Rev Sci Technol Sustain Dev 9(2-4):169-203

Levinsohn J, Petrin A (2003) Estimating production functions using inputs to control for unobservables. Rev Econ Stud 70(2):317-341

Lööf H, Hesmati A (2004) The impact of public funding on private r\&d investment. new evidence from a firm level innovation study (additionality or crowding out? on the effectiveness of R\&D subsidies) Technical report, CECIS, KTH Royal Institute of Technology

Lucas DS, Fuller CS (2017) Entrepreneurship: productive, unproductive, and destructive-relative to what? J Bus Ventur Insights 7:45-49

OECD (2016) OECD reviews of innovation policy: Sweden 2016, Technical report. OECD Publishing, Paris

Riksrevisionen (2016) Statliga stöd till innovation och företagande, Riksrevisionen, RiR 2016:22, Stockholm

Rovigatti G, Mollisi V (2016) PRODEST: Stata Module for production function estimation based on the control function approach. Statistical Software Components, Boston College Department of Economics

Silva AM, Silva ST, Carneiro A (2017) Determinants of grant decisions in R\&D subsidy programmes: evidence from firms and S\&T organisations in portugal. Sci Publ Policy 44(5):683-697

Söderblom A, Samuelsson M, Wiklund J, Sandberg R (2015) Inside the black box of outcome additionality: effects of early-stage government subsidies on resource accumulation and new venture performance. Res Policy 44(8):1501-1512

Stein WE (2002) Asymmetric rent-seeking with more than two contestants. Publ Choice 113(3):325-336

Svaleryd H, Vlachos J (2009) Political rents in a non-corrupt democracy. J Publ Econ 93(3-4):355-372

Takalo T, Tanayama T, Toivanen O (2013) Estimating the benefits of targeted R\&D subsidies. Rev Econ Stat 95(1):255-272

Tillväxtanalys (2014) Företagsstöd till innovativa små och medelstora företag, Technical Report 16, Tillväxtanalys

Tillväxtanalys (2015) Tillväxt genom stöd: en bok om statligt stöd till näringslivet, The Swedish Agency of Growth Policy Evaluations

Tingvall PG, Videnord J (2018) Regional differences in effects of publicly sponsored R\&D grants on SME performance. Small Business Economics. https://doi.org/10.1007/s11187-018-0085-6

Tullock G (1980) Efficient rent seeking. In: T. R. Buchanan JM, Tullock G (eds) Toward a theory of the rent-seeking society. College Station: Texas A\&M University Press, pp 97-112

Wooldridge JM (2005) Simple solutions to the initial conditions problem in dynamic, nonlinear panel data models with unobserved heterogeneity. J Appl Econ 20(1):39-54

Wooldridge JM (2009) On estimating firm-level production functions using proxy variables to control for unobservables. Econ Lett 104(3):112-114

Yamazaki T (2008) On the existence and uniqueness of pure-strategy nash equilibrium in asymmetric rentseeking contests. J Publ Econ Theory 10(2):317-327

Zúñiga-Vicente JÁ, Alonso-Borrego C, Forcadell FJ, Galán JI (2014) Assessing the effect of public subsidies on firm R\&D investment: a survey. J Econ Surv 28(1):36-67

Publisher's Note Springer Nature remains neutral with regard to jurisdictional claims in published maps and institutional affiliations. 